

\section{Sumário}

I. Crônicas do Direito Internacional ...............................................1

REPARAÇÃo DE VÍTIMAS À LUZ DE UM TRATAdo SOBRE EMPRESAS E DIREITOS HUMANOS ............ 3 Ana Cláudia Ruy Cardia

Consumer Social Responsibility as a Requirement for Corporate Social ResponsibiliTY

Nitish Monebhurrun

Crisis in Venezuela: The Brazilian response to the massive flow of Venezuelans in

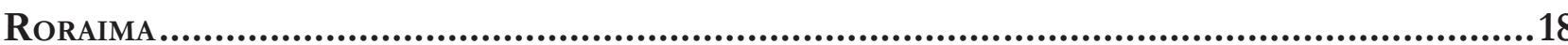

Jacqueline Salmen Raffoul

II. Dossiê EsPecial: Business and Human Rights.........................................23

Some remarks on the third sessions of the Business and Human Rights Treaty Pro-

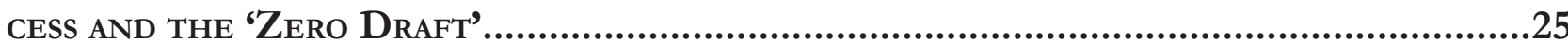

Humberto Cantú Rivera

The United Nations guiding principles on business and human Rights, the State

DUTY TO PROTECT HUMAN RIGHTS AND THE STATE-BUSINESS NEXUS.

Mihaela Maria Barnes

HARdening SOFT LAW: ARE THE EMERging Corporate SOCIAL DisClOSURE LAWS CAPABLE OF GENERATING SUBSTANTIVE COMPLIANCE WITH HUMAN RIGHTS?

Justine Nolan

Del Documento de Elementos al Draft 0: apuntes jurídicos respecto del posible CONTENIDO DEL PROYECTO DE INSTRUMENTO VINCULANTE SOBRE EMPRESAS TRANSNACIONALES

Y OTRAS EMPRESAS CON RESPECTO A LOS DERECHOS HUMANOS

Adoración Guamán 
ACCESS TO REMEDIES AND THE EMERGING ETHICAL DILEMMAS: CHANGING CONTOURS WITHIN THE BUSINESS-HUMAN RIGHTS DEBATE

Justin Jos

LA RESPONSABILIDAD PENAL DE LAS EMPRESAS POR GRAVES VIOLACIONES DE DERECHOS HUMANOS: PRÁCTICA ACTUAL Y DESAFÍOS FUTUROS 130

Daniel Iglesias Márquez

THE ENVIRONMENTAL LAW DIMENSIONS OF AN INTERNATIONAL BINDING TREATY ON BUSINESS AND HUMAN RIGHTS

Juan Gabriel Auz Vaca

Los Objetivos de Desarrollo Sostenible en Europa y su Intersección con el Marco de los Negocios y los Derechos Humanos

Paolo Davide Farah

HumAN RIGHTS AND MARKET ACCESS 203

Danielle Mendes Thame Denny

BusinesS AND HUMAN RIGHTS IN BRAZIL: EXPLORING HUMAN RIGHTS DUE DILIGENCE AND OPERATIONAL-LEVEL GRIEVANCE MECHANiSMS IN THE CASE OF KinRoss PARACATU Gold Mine...222 Mariana Aparecida Vilmondes Türke

Human Rights and eXtractive industries in Latin America: What Responsibility of CORPORATIONS AND THEIR STATES OF ORIGIN FOR HUMAN RIGHTS VIOLATIONS IN THE INTER-American Human Rights System?.

Alberto do Amaral Junior e Viviana Palacio Revello

MultinaCiOnAIS FAST FASHION E DIREITOS HUMANOS: EM BUSCA DE NOVOS PADRÕES DE RESPONSABILIZAÇÃO 255

Laura Germano Matos e João Luis Nogueira Matias

III. Artigos sobre outros temas

EFFICIENCY AND EFFICACY OF PUBLIC FOOD PROCUREMENT FROM FAMILY FARMERS FOR SCHOOL FEEDING IN BRAZIL. 271

Rozane Márcia Triches 
A relaÇão ENTRE O GRAU de INTEGRaÇÃo ECONÔMiCA E O SISTEMA DE SOLUÇÃo DE CONTROvÉRSIAS: UM ESTUdo COMPARATIVO ENTRE A UNIÃo EURopeia E O MERCOSUl.....................286

Luciane Klein Vieira e Elisa Arruda

THE RIGHTS TO MEMORY AND TRUTH IN THE INTER-AMERICAN PARADIGMS OF TRANSITIONAL JUSTICE: THE CASES OF BRAZIL AND CHILE 308

Bruno Galindo

Juliana Passos de Castro

A margem nacional de apreciação na Corte Interamericana de Direitos Humanos.325 Gilberto Schäfer, José Eduardo Aidikaitis Previdellie e Jesus Tupã Silveira Gomes

Novos Direitos FUNDAMENTAIS NO ÂMBITo DA UNASUL: ANÁLISE DAS AGENDAS DE Brasil E VENEZUELA À LUZ DO DIREITO À PAZ.

Pedro Pulzatto Peruzzo e Arthur Ciciliati Spada

A atuação do Grupo Mercado Comum frente À Criminalidade organizada transnacio-

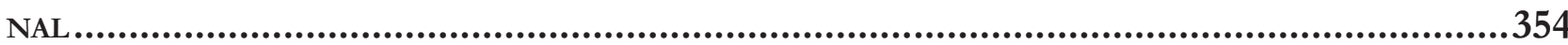

Sabrina Cunha Kesikowski, Luis Alexandre Carta Winter e Eduardo Biacchi Gomes

COUNTER-TERRORISM LEGISLATION AND TERRORIST ATTACKS: DOES HUMAN RIGHTS HAVE SPACE?

Heloisa Tenello Bretas e Daniel Damásio Borges

Territórios da ViolênCia de GÊNERo: NORMATIVA INTERNACIONAL E os Casos "CAMpo AlGodoeiro” (MÉXICO) - “Morro do Garrote” (BrasiL)

Eugênia Nogueira do Rêgo Monteiro Villa e Bruno Amaral Machado

O USO DE MECANISMOS INFORMAIS DE GOVERNANÇA GLOBAL E SUA APLICABILIDADE NAS LICITAÇÕES PÚBLICAS BRASILEIRAS.

Fabiano de Figueiredo Araujo e Paulo Afonso Cavichioli Carmona

Autonomia INSTITUCIONAL DA IGREJA CATÓliCA E A INGERÊNCIA INDEVIDA DO ESTADO BRASILEIRo POR EVENTUAIS Ilícitos CANÔNicos: ANÁlise do CASO de Formosa-GO, À luz do TraTADo Brasil-Santa SÉ de 2010 
A MORE TARGETED APPROACH TO FOREIGN DIRECT INVESTMENT: THE ESTABLISHMENT OF SCREENING SYSTEMS ON NATIONAL SECURITY GROUNDS

Carlos Esplugues Mota

IV. RESENHAS 467

Direito Internacional em Perspectiva Transcivilizacional de Yasuaki Onuma........469 Arthur Roberto Capella Giannattasio

Resenha do livro Space, Global Life: The Everyday Operation of International LaW and Development, de Luis Eslava .473

Matheus Gobbato Leichtweis

QUEM TEM MEDO DO PÓS-COLONIAL NO DIREITO INTERNACIONAL? UMA RESENHA DE "DECOLONISING INTERNATIONAL LAW: DEVELOPMENT, ECONOMIC GROWTH AND THE POLITICS OF UNIVERSAlity" de Sundhya Pahuja

Gabriel Antonio Silveira Mantelli

Direitos humanos COMO UM NOVO PROJETO PARA O Direito INTERNACIONAL? Notas sobre The Last Utopia, de Samuel Moyn .490 João Roriz 


\title{
The environmental law dimensions of an international binding treaty on business and human rights*
}

\author{
As dimensões do direito ambiental de um \\ tratado internacional vinculante sobre \\ empresas e direitos humanos
}

Juan Gabriel Auz Vaca**

\begin{abstract}
Multinational Corporations are present in virtually every corner of the world, generating not only economic growth but foremost human rights abuses linked to environmental degradation. In view of this, the United Nations Human Rights Council mandated an intergovernmental working group to draft a binding instrument on business and human rights, potentially drawing obligations for private commercial entities with a transnational character. In that context, an analysis of the on-going negotiations will be conducted to identify and discuss the environmental law dimensions embedded therein. A dialogue between the content of the travaux préparatoires of the treaty's drafting process - including the official reports of the three sessions and other relevant documents - and the evolution of international corporate environmental accountability, will yield some possible pathways for environmental protection linked to human rights. Furthermore, special importance will be given to discussions with respect to the obligations of corporations and its implications for the protection of the environment. Some findings will show that the current state of negotiations falls short in reflecting environmental dimensions from a legal perspective, although the tools that might be developed in the process could be moulded as to integrate them in forthcoming negotiations.
\end{abstract}

Keywords: International environmental law. Business and human rights. Binding treaty. Environmental rights. International human rights law.

* Recebido em 14/06/2018 Aprovado em 09/07/2018

** Juan Auz is an Ecuadorean attorney with experience in human rights and environmental issues. He is an Alexander von Humboldt Fellow at the Potsdam Institute for Climate Impact Research. Co-Founder of Terra Mater and legal advisor of Fundación Pachamama. He received his LL.B. from Universidad de las Americas in Quito and LL.M. on Global Environment and Climate Change Law from the University of Edinburgh.Email: juangauz@gmail.com

\section{Resumo}

As corporações multinacionais estão presentes em praticamente todos os cantos do mundo, gerando não só o crescimento econômico, mas principalmente os abusos dos direitos humanos ligados à degradação ambiental. Em vista disso, o Conselho de Direitos Humanos das Nações Unidas determinou que um grupo de trabalho intergovernamental redigisse um instrumento vinculante sobre as empresas e os direitos humanos, potencialmente estabelecendo obrigações para entidades comerciais privadas com caráter transnacional. Nesse contexto, uma análise das negociações em andamento 
será conduzida para identificar e discutir as dimensões do direito ambiental nele incorporado. Um diálogo entre o conteúdo dos travaux préparatoires do processo de elaboração do tratado - incluindo os relatórios oficiais das três sessões e outros documentos relevantes - e a evolução da responsabilidade ambiental corporativa internacional, trará alguns caminhos possíveis para a proteção ambiental ligada aos direitos humanos. Além disso, especial importância será dada às discussões sobre as obrigações das empresas e suas implicações para a proteção do meio ambiente. Algumas descobertas mostrarão que o estado atual das negociações é insuficiente para refletir as dimensões ambientais do ponto de vista jurídico, embora as ferramentas que possam ser desenvolvidas no processo possam ser moldadas de modo a integrá-las nas próximas negociações.

Palavras-chave: Direito ambiental internacional. Empresas e direitos humanos. Tratado vinculante. Direitos ambientais. Direito internacional dos direitos humanos.

\section{INTRODUCTION}

Globalization has contributed to the proliferation of manifold markets around the world, giving rise to numerous Multinational Corporations (MNCs), ${ }^{1}$ whose operations transcend regulatory frameworks and jurisdictions of any given state, ${ }^{2}$ concurrently moulding the values to which our society adheres. ${ }^{3}$ MNCs accrued larger revenues than the figures shown in the top economies' GDPs, ${ }^{4}$ suggesting an important extent of influence in the design and implementation of internatio-

1 UNITED NATIONS. Commentary on the norms on the responsibilities of transnational corporations and other business enterprises with regard to human rights. UN Doc E/CN4/Sub2/2003/38/Rev2, 2003., para. 20 . For the purposes of this document, the term MNC corresponds to that of Transnational Corporations (TNCs), generically defined in the Norms as 'an economic entity operating in more than one country or a cluster of economic entities operating in two or more countries - whatever their legal form'.

2 MCBETH, Adam. Human rights in economic globalisation. In: JOSEPH, Sarah; MCBETH, Adam (Ed.). Research handbook on international human rights law. Edward Elgar, 2010. p. 139-141.

3 WETTSTEIN, Florian. Multinational corporations and global justice: human rights obligations of a quasi-governmental institution. Stanford Business Books, 2009. p. 167.

4 TRIVETT, Vincent et al. 25 US mega corporations: where they rank if they were countries. Available in: Business Insider at: <http:/ / www.businessinsider.com/25-corporations-bigger-tan-countries-2011-6>. nal norms. ${ }^{5}$

Moreover, while it is unmistakable that MNCs have stimulated global economic growth, the negative impacts on human rights and the environment generated directly or indirectly by them should not be overlooked, especially in a context where their operations are being outsourced to developing countries, giving rise to a 'disproportionate impact of lawful pollution' linked to their 'operational policies, decisions, practices and production activities', ${ }^{6}$ being carried out in practically de-regularized jurisdictions. A quotidian dramatic reality particularly for local communities highly dependent upon natural resources.

Corporate Social Responsibility (CSR), a concept coined in the $50 \mathrm{~s}$, intends to contribute to the "well-being and progress of individuals and society" ${ }^{8}$. However, it has not fully embraced a human rights perspective.' This has led human rights victims to find ways to hold MNCs liable in host ${ }^{10}$ countries' jurisdictions; disentangling sophisticated contracts between parent companies with multiple suppliers in de-localized jurisdictions, ${ }^{11}$ and attempting to lift corporate veils ${ }^{12}$ to prevent impunity of MNCs domiciled in their home countries.

These legal challenges are the consequence of a vacuum in international law, mainly due to few eviden-

5 WETTSTEIN, Florian. Multinational corporations and global justice: human rights obligations of a quasi-governmental institution. Stanford Business Books, 2009. p.168.

6 SCHWARTZ, Priscilla. Corporate activities and environmental justice: perspectives on Sierra Leone's mining. In: EBBESSON, Jonas; OKOWA, Phoebe (Ed.). Environmental law and justice in context. Cambridge University Press, 2009. p. 432.

7 K. ANTON, Donald; SHELTON, Dinah. Environmental protection and human rights. Cambridge University Press, 2011. p. 132.

8 RAMASASTRY, Anita. Corporate social responsibility versus business and human rights: bridging the gap between responsibility and accountability. Journal of Human Rights, v. 14, n. 2, p. 237-259, jun. 2015.

9 RAMASASTRY, Anita. Corporate social responsibility versus business and human rights: bridging the gap between responsibility and accountability. Journal of Human Rights, v. 14, n. 2, p. 237-259, jun. 2015.

10 All along this text, 'home country' will be defined as the territory or jurisdiction where the parent company is registered or incorporated, whereas 'host country' is where the company, or a subsidiary, operates outside the jurisdiction or territory of its home country.

11 MORGERA, Elisa. Multinational corporations and international environmental law. In: ALAM, Shawkat et al. (Ed.). Routledge handbook of international environmental law. Routledge, 2015. p. 190.

12 MORGERA, Elisa. Corporate accountability in international environmental law. United Kingdom: Oxford University Press, 2009. p. 28. 
ce of 'direct liability of corporations when [breaching] obligations with regard to human rights ${ }^{13}$ or international environmental law (IEL), ${ }^{14}$ ratifying that said duties are consigned exclusively upon states.

In view of this, the first attempt to regulate MNCs through international legislation in a universal and more stringent fashion was first initiated in the 70 s by the United Nations Economic and Social Council, which created a UN Commission on Transnational Corporations in order to draft a Code of Conduct for Transnational Corporations (UNCCTC) $;{ }^{15}$ an attempt that was stalled by negotiations collapse in $1992,{ }^{16}$ partially due to the widespread perception that the paradigm surrounding regulation might encumbering businesses' development. Subsequently, 'partnership approaches' and soft-law guidelines ${ }^{17}$ gave rise to some voluntary initiatives endorsed by intergovernmental organizations, such as the UN Global Compact (GC) in 2000, an initiative still in progress aiming to implement ten universal sustainability principles that derive from main international human rights instruments, with more than 10,000 companies as participants. ${ }^{18}$

In 1997, the UN Sub-Commission on the Promotion and Protection of Human Rights prepared the 'Norms on the Responsibilities of Transnational Corporations and Other Business Enterprises with Regard to Human Rights' (the Norms), ${ }^{19}$ an initiative focused in human rights and environmental direct responsibilities

13 KHAN, Wasima. Corporate power and the protection of human rights in equilibrium. Security and Human Rights, v. 24, n. 1, p. 29-42, 2013.

14 BIRNIE, Patricia; BOYLE, Alan; REDGWELL, Catherine. International law and the environment. 3. ed. United Kingdom: Oxford University Press, 2009. p. 328.

15 BUHMANN, Karin. The development of the "UN framework": a pragmatic process towards a pragmatic output. In: MARES, Radu (Ed.). The UN guiding principles on business and buman rights: foundations and implementation. Martinus Nijhoff, 2012. p. 87.

16 MORGERA, Elisa. Multinational corporations and international environmental law. In: ALAM, Shawkat et al. (Ed.). Routledge handbook of international environmental law. Routledge, 2015. p. 193.

17 MORGERA, Elisa. The UN and corporate environmental responsibility: between international regulation and partnerships. Review of European Community and International Environmental Law, v. 15, n. 1, p. 93-109, 2006.

18 WEISSBRODT, David. Human rights standards concerning transnational corporations and other business entities. Minnesota Journal of International Law, v. 23, n. 2, p. 135-171, 2014.

19 LÓPEZ, Carlos. The "ruggie process": from legal obligations to corporate social responsibility? In: DEVA, Surya; BILCHITZ, David (Ed.). Human rights obligations of business. Cambridge University Press, 2013. p. 62. for companies, differing in that aspect with the GC. ${ }^{20}$ However, its anti-hortatory content subtracted political recognition, ${ }^{21}$ leading to a decline of endorsement by the former UN Commission on Human Rights (UNCHR) in 2003. ${ }^{22}$

In order to overcome past political stalemates, in 2005 the UNCHR requested the Secretary-General to appoint a special representative on the issue of human rights and transnational corporations and other business enterprises (SRSG) to submit recommendations and clarifications on the issue..$^{23}$ Professor John Ruggie assumed this position, who later developed the UN Framework on Business and Human Rights (UNFBHR) in $2008^{24}$ and operationalized it through a set of 'Guiding Principles' on business and human rights (UNGP) in 2011. ${ }^{25}$ Both initiatives were endorsed unanimously by the Human Rights Council (HRC) ${ }^{26}$ and rest upon three pillars: 'Protect, Respect and Remedy' human rights. ${ }^{27}$

Despite a diverse range of opinions, it could be said that today, the UNGP and the OECD Guidelines for Multinational Enterprises, ${ }^{28}$ are the most prominent soft-law instruments that bring corporations and governments together to respect human rights, ${ }^{29}$ howe-

20 WEISSBRODT, David. Human rights standards concerning transnational corporations and other business entities. Minnesota Journal of International Law, v. 23, n. 2, p. 135-171, 2014.

21 MORGERA, Elisa. Multinational corporations and international environmental law. In: ALAM, Shawkat et al. (Ed.). Routledge handbook of international environmental law. Routledge, 2015. p. 201.

22 LÓPEZ, Carlos. The "ruggie process": from legal obligations to corporate social responsibility? In: DEVA, Surya; BILCHITZ, David (Ed.). Human rights obligations of business. Cambridge University Press, 2013. p. 62.

23 UN OFFICE OF THE HIGH COMMISSIONER FOR HUMAN RIGHTS. Human rights and transnational corporations and other business enterprises. E/CN.4/RES/2005/69, para. 1, 2005.

24 RUGGIE, John. Protect, respect and remedy: a framework for business and human rights: report of the special representative of the secretary-general on the issue of human rights and transnational corporations and other business enterprises, A/HRC/8/5, 2008.

25 RUGGIE, John. Guiding principles on business and buman rights: implementing the United Nations "protect, respect and remedy" Framework. A/HRC/17/31, 2011.

26 UNITED NATIONS HUMAN RIGHTS COUNCIL. Human rights and transnational corporations and other business enterprises. A/ HRC/RES/17/4, para. 1, 2011.

27 RUGGIE, John. Just business: multinational corporations and human rights. W. W Norton \& Company, 2013. p. 6.

28 ORGANISATION FOR ECONOMIC CO-OPERATION AND DEVELOPMENT. OECD guidelines for multinational enterprises, 2011.

29 RUGGIE, John. Just business: multinational corporations and human rights. W. W Norton \& Company, 2013. p. 84. 
ver, since their adoption and further implementation, several governments and NGOs have been pushing the HRC's agenda $\mathrm{a}^{30}$ in order to resit discussions on a legally binding business and human rights treaty (BHRT).

This led to a resolution on 26 June 2014 to establish an open-ended intergovernmental working group (OEIGWG) to elaborate a BHRT, ${ }^{31}$ which had its first round of negotiations in 2015, and two yearly consecutive sessions in 2016 and 2017, providing a new forum where countries could raise concerns about the inclusion of environmental issues therein. ${ }^{32}$

This process could entail multiple outcomes, such as contributing at 'redressing gaps and imbalances in the international legal order that undermine $[. .$.$] victims of$ corporate human right abuses, ${ }^{33}$ or on the contrary, it could be an attempt to repeat history by emulating the unsuccessful destiny of the Norms or the UNCCTC.

Moreover, the environmental dimensions within the discussions of an instrument that might regulate the behaviour of businesses certainly will be taken into consideration, as humanity is facing multi-faceted challenges where ecological considerations are ubiquitous in the Anthropocene epoch, ${ }^{34}$ which could be explain why in nearly a third of cases involving corporations around the world, alleged environmental harms had corresponding impacts on human rights. ${ }^{35}$

Despite the inextricably link between environmental harm and human rights violations, law has not entirely

30 RUGGIE, John. The past as prologue?: a moment of truth for UN business and human rights treaty. Available in: <https://www. hks.harvard.edu/m-rcbg/CSRI/Treaty_Final.pdf $>$.

31 LAGOUTTE, Stéphanie. New challenges facing states within the field of human rights and business. Nordic Journal of Human Rights, v. 33, n. 2, p. 158-180, 2015.

32 MOHAMADIEH, Kinda; URIBE, Daniel. Business and buman rights: commencing discussions on a legally binding instrument. South Centre Bulletin. Available in: <http://www.southcentre.int/ wp-content/uploads/2015/11/SB87-88_EN.pdf>.

33 UNITED NATIONS HUMAN RIGHTS COUNCIL. Report on the first session of the open-ended intergovernmental working group on transnational corporations and other business enterprises with respect to buman rights, with the mandate of elaborating an international legally binding instrument. A/HRC/31/50, 2016. para. 4.

34 STEFFEN, Will; CRUTZEN, Paul; MCNEILL, John. The anthropocene: are humans now overwhelming the great forces of nature? Ambio, v. 36, n. 8, p. 614-621, 2007.

35 RUGGIE, John. Report of the special representative of the secretarygeneral on the issue of buman rights and transnational corporations and other business enterprises. Addendum: corporations and human rights: a survey of the scope and patterns of alleged corporate-related human rights abuse. A/HRC/8/5/Add.2, 2008. para. 7. echoed its importance nor made a substantial effort to understand its underpinnings, since in 'general academic treatments of human rights law, $[. .$.$] there is almost$ no debate on the relationship between human rights and the environment, ${ }^{36}$ nor an important exploration of 'the usefulness of [IEL] in addressing human rights-related concerns about corporate conduct'. ${ }^{37}$ This spurs a problematic scenario, given that 'unlike the field of human rights, where most violations are committed by state agents, environmental harm largely stems from actions of the private sector ${ }^{38}$ in general, and MNCs in particular. ${ }^{39}$

Overall, the objective of this writing is to examine the environmental dimensions subtly entrenched within the prospective BHRT, currently being developed under the auspices of the HRC. Firstly, a brief contextual introduction on the practical and theoretical inter linkages between international human rights law (IHRL) and IEL in the context of corporate accountability will be explored. Secondly, the shortcomings and opportunities of past initiatives aimed at rendering MNCs accountable - emphasizing on UN initiatives, will be examined. Thirdly, some light will be shed on different issues involving the protection of the environment embedded in the negotiations of the BHRT. By comparing the evolution of the discussions around corporate accountability undertaken in the past and simultaneously relying on IEL instruments, possible pathways for environmental protection linked to human rights will be spelled out. Furthermore, special importance will be given to discussions with respect to duties directly assumed by corporations and its implications for the protection of the environment.

36 BOYLE, Alan. Human rights and the environment: where next?. European Journal of International Law, v. 23, n. 3, p. 613-642, 2012.

37 MORGERA, Elisa. Benefit-sharing as a bridge between the environmental and human rights accountability of multinational corporations. In: Ben Boer (Ed.). Environmental law dimensions of buman rights. United Kingdom: Oxford University Press, 2015. p. 45.

38 K. ANTON, Donald; SHELTON, Dinah. Environmental protection and human rights. Cambridge University Press, 2011. p. 131.

39 NOLLKAEMPER, André. Responsibility of transnational corporations in international environmental law: three perspectives. In: WINTER, Gerd (Ed.). Multilevel governance of global environmental change. United Kingdom: Cambridge University Press, 2006. p. 180. 


\section{HuMAN RIGHTS, THE ENVIRONMENT AND INTERNATIONAL LAW IN THE CONTEXT OF CORPORATE ACCOUNTABILITY}

Principle 1 of the Rio Declaration placed human species at the centre of concerns for sustainable development ${ }^{40}$, giving rise to the concept of having a healthy life in harmony with nature; ${ }^{41}$ as a result, a convergence of three dimensions emerged: human rights, environmental protection and sustainable development. This conjunction is reflected in several international instruments designed by the interplay of socio-economic dynamics and diplomatic efforts, under the overarching paradigm of globalization, ${ }^{42}$ where tensions between economic interests - predominantly identified with MNCs - and environmental protection are prevalent. ${ }^{43}$

With that said, this chapter will attempt to briefly explore the interactions of corporations with international law related to both: human rights and the environment.

\subsection{MNCs under international law: an overview}

A 'corporation' may be defined as a legal fictional abstraction, separated from the personality of its constituents and shareholders, of 'limited liability and licensed by the state for the purpose of conducting profit-seeking business activity'. ${ }^{44}$ Contrariwise, behind the definition of a MNC lies an intrinsic elusive character, indicating its highly mutable nature. Although, irrespective of this fact, MNCs do share several common features, like their presence in more than one country through coordinated subsidiaries motivated by profit

40 FRANCIONE, Francesco. Principle 1: human beings and the environment. In: VIÑUALES, Jorge (Ed.). The Rio declaration on environment and development: a commentary. United Kingdom: Oxford University Press, 2015. p. 94.

41 UNITED NATIONS. Conventions and agreements international developments. Commonwealth Law Bulletin, v.19, n. 1, p. 247316, 1993.

42 BOYLE, Alan; CHINKIN, Christine. The making of international law. United Kingdom: Oxford University Press, 2007. p. 21.

43 DUPUY, Pierre-Marie. International environmental law: looking at the past to shape the future. In: DUPUY, Pierre-Marie; VIÑUALES, Jorge (Ed.). Harnessing foreign investment to promote environmental protection: incentives and safeguards. United Kingdom: Cambridge University Press, 2013. p. 19.

44 KRAVIAS, Markos. Corporate obligations under international law. United Kingdom: Oxford University Press, 2013. p. 4. earning. ${ }^{45}$ Part of their diversity lies on their size and 'multinational spread'; ${ }^{46}$ paving their way through unrestricted markets, and sometimes attracted by new frontiers with less regulated jurisdictions. ${ }^{47}$

Considering that MNCs are fundamental global actors, capable of prominently influencing international law due to their transnational powers - subduing even the role of several nations, discussions on whether MNCs are subjects or objects, or have rights and duties under international law, have not been exhausted; mainly because the state, as the exclusive duty-bearer, is a paradigm posited as inadequate under current socio-economic contexts. ${ }^{48}$

MNCs outsource their operations onto developing countries - where most of the times standards are less stringent, yielding profit not only from the low costs that those operations involve, but also from the guarantees provided by Bilateral Investment Treaties (BITs), which in some cases consider human rights and the environmental domestic law as a risk for foreign investments. $^{49}$

International law has not been able to provide homogenous definitions and categories linked to corporations' nature, a lacuna cautiously addressed by the ICJ in the Barcelona Traction case, stating that municipal law should supplement any absence of definition in international law ${ }^{50}$.

However, municipal law cannot decide if MNCs have personhood or not under international law. For instance, if corporations become new subjects of international law, they would freely amend bilateral treaties,

45 MORGERA, Elisa. Corporate accountability in international environmental law. United Kingdom: Oxford University Press, 2009. p. 59.

46 SHAW, Malcolm. International law. 6. ed. United Kingdom: Cambridge University Press, 2008. p. 250.

47 SADELEER Nicolas de. Environmental justice and international trade law. In: EBBESSON, Jonas; OKOWA, Phoebe (Ed.). Environmental law and justice in context. United Kingdom: Cambridge University Press, 2009. p. 448.

48 ZAHARAI, Constantin et al. Transnational corporations, international law and human rights. Economics, Management \& Financial Markets, v. 6, n. 4, p. 138-143, 2011.

49 MACLEAY, Fiona. Corporate codes of conduct and the human rights accountability of transnational corporations: a small piece of a larger puzzle. In: SCHUTTER, Olivier De (Ed.). Transnational corporations and human rights. Hart Pub, 2006. p. 220.

50 INTERNATIONAL COURT OF JUSTICE. International Court of Justice Reports of Judgments, Advisory Opinions and Orders. Barcelona traction, light and power company, limited, judgment Belgium v Spain, 1970. p. 3. 
a task classically restricted to interstate relations, ${ }^{51}$ but also home states would no longer 'retain the right to waive the right of their investors to file a claim'. ${ }^{52}$

Hence, handing over personhood to corporations an scenario not yet crystallized under international law, ${ }^{53}$ might 'threaten to remove the element of state control from such important questions and may threaten the credibility of international law itself,${ }^{54}$ thus potentially broadening historic power imbalances.

For the time being, corporations' identity under international law is not carved in stone; and while they can be referred as key 'participants' in the continuous international law-making process, or defined as subjects in the sense of its locus standi before specific international tribunals, ${ }^{55}$ the need for improving the design of corporate accountability measures should not be restrained by this on-going debate.

Unquestionably, corporations are subjects of law under domestic law, and some treaties ratified by their home states may bestow them human rights, ${ }^{56}$ or other category of rights embedded in thousands of $\mathrm{BITs},{ }^{57}$ conferring them a 'fair treatment, contract enforcement, protection against expropriation, and compensation for violations of their rights'. ${ }^{58}$

Moreover, the idea of corporate duties or obligations under IHRL which would allow to render MNCs directly liable, contradicts the classic doctrine where states are the legitimate bearers of said obligation, and not

51 ALVAREZ, Jose. Are corporations "subjects" of international law? Santa Clara Journal of International Law, v. 9, n. 1, 2011.

52 ALVAREZ, Jose. Are corporations "subjects" of international law? Santa Clara Journal of International Law, v. 9, n. 1, 2011.

53 SHAW, Malcolm. International law. 6. ed. United Kingdom: Cambridge University Press, 2008. p. 250.

54 ALVAREZ, Jose. Are corporations "subjects" of international law? Santa Clara Journal of International Law, v. 9, n. 1, p. 25, 2011.

55 MUCHLINSKI, Peter. Corporations in international law. In: WOLFRUM, Rudiger (Ed.). Max Planck encyclopaedia of public international law. United Kingdom: Oxford University Press, 2014. para. 7. 56 SCHRÖDER, Meinhard. Precautionary approach/principle. In: WOLFRUM, Rudiger (Ed.). Max Planck encyclopaedia of public international law. United Kingdom: Oxford University Press, 2014.

57 UNITED NATIONS CONFERENCE ON TRADE AND DEVELOPMENT. Global value chains: investment and trade for development. 2013. p. 101. In 2013, around 339 International Investment Agreements and 2857 BITs were concluded.

58 STEPHENS, Beth. Are corporations people?: corporate personhood under the constitution and international law: an Essay in honor of professor Roger S. Clark. Rutgers Law Journal, v. 44, n. 1, p. 1-31, 2013. private entities. ${ }^{59}$ This notion is currently widely supported by the international human rights legal corpus, ${ }^{60}$ and partly by literature. ${ }^{61}$

A similar phenomenon is reflected in IEL, where private actors do not have direct duties, ${ }^{62}$ and while some liability regimes regarding pollution do take note of direct liability on private actors, ${ }^{63}$ its application is only effective via the will of contracting states, ${ }^{64}$ resorting the matter in national jurisdictions. Therefore, currently there are not international environmental norms ${ }^{65}$ nor customary international law ${ }^{66}$ directly binding upon private companies in general and MNCs in particular.

Overall, international law is currently not well-equipped to hold MNCs liable in a direct manner, and even if these entities could be deemed as subjects of international law under certain circumstances, its fluid personality allows them to circumvent obligations under international law. However, given that the legal architecture of the corporation is similar to that of recogni-

59 NOLAN, Justine. The corporate responsibility to respect human rights: soft law or not law? In: DEVA, Surya; BILCHITZ, David (Ed.). Human rights obligations of business. United Kingdom: Cambridge University Press, 2013. p. 146.

60 KATUOKA, Saulius; DAILIDAITE, Monika. Responsibility of transnational corporations for human rights violations: deficiencies of international legal background and solutions offered by national and regional legal tools. Jurisprudencija, v. 19, n. 4, p. 13011316, 2012.

61 SCHRÖDER, Meinhard. Precautionary approach/principle. In: WOLFRUM, Rudiger (Ed.). Max Planck encyclopaedia of public international law. United Kingdom: Oxford University Press, 2014. p. 30.

62 MALJEAN-DUBOIS, Sandrine; RICHARD, Vanessa. The applicability of international environmental law to private enterprises. In: DUPUY, Pierre-Marie; VIÑUALES, Jorge (Ed.). Harnessing foreign investment to promote environmental protection. United Kingdom: Cambridge University Press, 2013. p. 94.

63 INTERNATIONAL MARITIME ORGANIZATION. International convention on civil liability for oil pollution damage. The American Journal of International Law, v. 64, n. 2, p. 481, 1970; INTERNATIONAL MARITIME ORGANIZATION. International convention on the establishment of an international fund for compensation for oil pollution damage: 1971. Environmental Policy and Law, v. 13, n. 2, p. 61-65, 1984. p. 61-65; COUNCIL OF EUROPE. Convention on civil liability for damage resulting from activities dangerous to the environment. International Legal Materials, v. 32, n. 5, p. 1228-1246, 1993.

64 JONGE, Alice de. Transnational corporations and international law: accountability in the global business environment. Edward Elgar Pub, 2011. p. 146.

65 MORGERA, Elisa. Corporate accountability in international environmental law. United Kingdom: Oxford University Press, 2009. p. 72.

66 BIRNIE, Patricia; BOYLE, Alan; REDGWELL, Catherine. International law and the environment. 3. ed. United Kingdom: Oxford University Press, 2009. p. 326. 
zed subjects of international law, such as states, in the sense that they both share the status of juristic person, establishing international legal obligations upon them, should not be considered as an impossible conceptual legal challenge. ${ }^{67}$

Thus, it could be said that the state-centred paradigm of international law has widened a legal chasm that a new binding treaty might be looking to sew up in tandem with soft-law initiatives, where direct obligations for companies could be outlined.

\subsection{Human rights violations in relation to environmental degradation: Corporations under the spotlight}

In 2010, global Foreign Direct Investment (FDI) exceeded $\$ 21,288.5$ billion, and the number of MNCs was estimated at over 100,000. ${ }^{68}$ Furthermore, the share of global FDI from MNCs registered in emerging markets has grown from 10 per cent in 2000 to 40 per cent in $2013,{ }^{69}$ denoting a likely impact in new frontiers where the pressure on the extraction of natural resources has not yet been consolidated, hence, not only increasing the chances of FDI opportunities, but most importantly, heightening the risks of human rights violations. ${ }^{70}$

Thus, the traditional narrative of western MNCs involved in breaches of human rights and environmental regulations in developing host states is now shifting to include local companies registered in those very same developing countries with inchoate institutions and an incipient rule of law - like MNCs originated from BRICS. ${ }^{71}$

67 KRAVIAS, Markos. Corporate obligations under international law. United Kingdom: Oxford University Press, 2013. p. 7.

68 JAWOREK, Małgorzata; KUZEL, Marcin. Transnational corporations in the world economy: formation, development and present position. Copernican Journal of Finance \& Accounting, v. 4, n. 1, p. 55-77, 2015.

69 CHEN, Victor; JOHNSON, Lise. Emerging market MNEs and social responsibility: an institutional pressure perspective. Transnational Corporations, v. 22, n. 3, p. 1-4, 2013.

70 COTULA, Lorenzo. Property in a shrinking planet: fault lines in international human rights and investment law. International Journal of Law in Context, v. 11, n. 2, p. 113-134, 2015.

71 HOBBES, Michael. The untouchables. Foreign Policy, 2016. Available in: <https://foreignpolicy.com/2016/04/11/the-untouchables-zimbabwe-green-fuel-multinational-corporations $/>$.; GRADL, Christina et al. Fast growth and big impacts: how emerging market multinationals are advancing sustainable development. Deutsche Gesellschaft für Internationale Zusammenarbeit (GIZ), 2011. p. 11. Although several MNCs from emerging market countries have dem-
Either way, regardless of jurisdiction, a breach of law by a private actor, amounting to human rights and environmental malfeasance, is usually generated by the tension between the right to pursue an economic endeavour on the one hand, and the rights of the people affected by those endeavours on the other. ${ }^{72}$ This conflict of values can theoretically explain the interplay between human rights and the environment in its various forms, ${ }^{73}$ and also be illustrated in several renowned cases around the world.

The harm on human rights and the environment caused by MNCs is often determined by the negligence of the parent company's supplier or a franchise thereof at some stage of the supply chain, normally operating in a developing country that seeks to attract FDI through lax environmental regulations, weak labour conditions, an ineffective judiciary system and an unstructured rule of law. ${ }^{74}$

Bhopal disaster in India, generated by the MNC Union Carbide, resulted in a death toll of 2.100 people and 200.000 people injured, let alone livestock and agricultural loss. ${ }^{75}$ In this case, even if plaintiffs sought recourse in the US - the jurisdiction of the parent company, the case was dismissed. ${ }^{76}$ Moreover, cases like Bhopal are just a symptom of a pervasive phenomenon, underlining that the vast majority of victims are poor communities, highly vulnerable to the practices of MNCs and their suppliers. ${ }^{77}$

onstrated good examples of positive impacts on local populations, indicating that corporate behaviour is not monolithic.

72 AFFOLDER, Natasha. Square pegs and round holes?. In: BOER, Ben (Ed.). Environmental law dimensions of human rights. United Kingdom: Oxford University Press, 2015. p. 35.

73 BIRNIE, Patricia; BOYLE, Alan; REDGWELL, Catherine. International law and the environment. 3. ed. United Kingdom: Oxford University Press, 2009. p. 271. Three perspectives on environmental rights are developed: first, procedural human rights can serve environmental related purposes; the self-standing right to a healthy environment as an economic, social and cultural right; and a collective right to the environment.

74 BAUMANN-PAULY, Dorothée; POSNER, Michael. Making the business case for human rights: an assessment. In: BAUMANNPAULY, Dorothée; NOLAN, Justine (Ed.). Business and human rights: from principles to practice, Routledge, 2016. p. 12.

75 UNITED STATES OF AMERICA. United States District Court for the Southern District of New York. In: Re union carbide corp gas plant disaster at bhopal. 634 f., supp. 842, 2, 1986.

76 UNITED STATES OF AMERICA. United States District Court for the Southern District of New York. In: Re union carbide corp gas plant disaster at bhopal. 634 f., supp. 842, 2, 1986.

77 RUGGIE, John. Report of the special representative of the secretarygeneral on the issue of buman rights and transnational corporations and other 
In addition, emblematic cases around the world, which share analogous factual features as $\mathrm{Bhopal}^{78}$ may entail additional intricacies that reveal the complexity of the problem: from the violation of environmental defenders' right in the context of MNCs' operations in collusion with state actors, ${ }^{79}$ to the potential transboundary human rights violations ${ }^{80}$ linked to $\mathrm{CO} 2$ emissions from MNCs of fossil fuel industries. ${ }^{81}$

Clearly, finding a coherent convergence between IHRL and IEL to tackle corporations' misconducts is not a facile task, especially considering that the connections between human rights and the environment via IHRL instruments has been surprisingly recent. The evidence is that seminal human rights treaties, such as the UDHR and the two core human rights covenants ${ }^{82}$

business enterprises. Addendum: corporations and human rights: a survey of the scope and patterns of alleged corporate-related human rights abuse. A/HRC/8/5/Add.2, 2008. para. 67.

78 UNITED STATES OF AMERICA. United States District Court for the Northern District of California. Bowoto v Chevron Corp. ND Cal 481 f., supp. 2d, 1010, 2007.; UNITED STATES OF AMERICA. United States District Court for the Central district of California. Doe v Unocal Corp. CD California 963 f., supp. 880, 1997.; UNITED STATES OF AMERICA. United States District Court for the Southern District of New York. Flores v Southern Peru Copper. 253 f., supp. 2d, 510, 2002.; UNITED STATES OF AMERICA. United States Supreme Court. Kiobel et al v Royal Dutch Petroleum Co et al. n. 10-1491, 2013.; UNITED KINGDOM. House of Lords. Lubbe v Cape PLC. UKHL 41, 2000.; UNITED STATES OF AMERICA. United States District Court for the Southern District of New York. Aguinda v Texaco, Inc. 142 f., supp. 2d, 534, 2001.; AUSTRALIA. Supreme Court of Victoria at Melbourne. Gagarimabu v Broken Hill proprietary co Ltd, VSC 517, 2001.; CANADA. British Columbia Supreme Court. Garcia v Tahoe resources inc. BCSC 2045, 2015.; CANADA. Québec Canadian Court of Appeal. Bil'in village council v Park. QCCA 2470, 2008.

79 FORST, Michel. Situation of human rights defenders: report of the special rapporteur on the situation of human rights defenders. A/70/217, 2015.

80 KNOX, John. Report of the special rapporteur on the issue of human rights obligations relating to the enjoyment of a safe, clean, healthy and sustainable environment. A/HRC/31/52, 2016. para. 9; UNITED NATIONS HUMAN RIGHTS COUNCIL. Elaboration of an international legally binding instrument on transnational corporations and other business enterprises with respect to human rights. UN. Doc. A/HRC/RES/26/9, 2014.; OFFICE OF THE UNITED NATIONS HIGH COMMISSIONER FOR HUMAN RIGHTS. Report of the Office of the United Nations High Commissioner for Human Rights on the Relationship between Climate Change and Human Rights. Annual Report A/ HRC/10/61, 2009, para. 78. It is noteworthy to clarify that such contributions do not constitute a violation of rights in strict rigour. 81 INTERGOVERNMENTAL PANEL ON CLIMATE CHANGE (Ed.). Climate Change 2014: synthesis report, 2015. p. 5. Fossil fuel industry contributed with nearly $78 \%$ of the total level of emissions between 1970 and 2010.

82 UNITED NATIONS. Official documents United Nations human rights covenants: international covenant on economic, so- do not mention a self-standing right to a healthy environment, narrowing the environmental protection as a 'green' extension of the rights already recognized therein, ${ }^{83}$ even though the right to a healthy environment is already present in regional treaties around the world, ${ }^{84}$ and in more than 100 countries' constitutions. ${ }^{85}$

The fact is that 'greening' human rights has been successful in connecting environmental degradation and impairments of substantive (right to life, health, housing, access to water and private family life), and procedural rights (access to justice, public participation, transparency and access to information), ${ }^{86}$ including collective rights of indigenous peoples such as the right to a free, prior and informed consent (FPIC). ${ }^{87}$ This is evinced by UN human rights treaty bodies, ${ }^{88}$ the HRC, ${ }^{89}$ and even regional human rights bodies, who have established the prominence of environmental considerations as essential conditions to the full realization of human rights. ${ }^{90}$

cial and cultural rights, international covenant on civil and political rights, optional protocol to the international covenant on civil and political Rrights. American Journal of International Law, v. 61, n. 3, p. 861-890, 1967.

83 KNOX, John. Greening human rights. OpenDemocracy, $14 \mathrm{Jul}$ 2015. Available in: <https://www.opendemocracy.net/openglobalrights/john-knox/greening-human-rights $>$.

84 ORGANIZATION OF AFRICAN UNITY. African charter on human and peoples' rights. OAU Doc. CAB/LEG/67/3 rev, 1981. art. 24; ORGANISATION OF AMERICAN STATES. Additional protocol to the american convention on human rights in the area of economic, social and cultural rights, 1988. art. 11; LEAGUE OF ARAB STATES. Arab charter on human rights, 2004. art. 38; ASSOCIATION OF SOUTHEAST ASIAN NATIONS, ASEAN Human Rights Declaration, 2012, art.28(f); UNITED NATIONS ECONOMIC COMMISSION FOR LATIN AMERICA AND THE CARIBBEAN. Regional agreement on access to information, participation and justice in environmental matters in Latin America and the Caribbean. 2018.

85 BOYD, David. Constitutional right to a healthy environment, the feature: environmental causes and the Law. Law Now, v. 37, n. 4, p. $9-13,2012$.

86 KNOX, John. Report of the independent expert on the issue of buman rights obligations relating to the enjoyment of a safe, clean, healthy and sustainable environment, compilation of good practices. UN Doc. A/HRC/28/61, 2015. para. 25.

87 MORGERA, Elisa. Corporate accountability in international environmental law. United Kingdom: Oxford University Press, 2009. p. 142.

88 UNITED NATIONS. Review of the composition, organization and administrative arrangements of the sessional working group on the implementation of the international covenant on economic, social and cultural rights. E/1982/L.35/Rev.1, 1985.

89 UNITED NATIONS HUMAN RIGHTS COUNCIL. Human rights and the environment. UN Doc. A/HRC/RES/25/21, 2014. 90 ORELLANA, Marcos; KOTHARI, Miloon; CHAUDHRY, Shivani. Climate change in the work of the committee on economic, social and cultural rights. Geneva: Friedrich Ebert Stiftung, 2010. p. 20. 
Therefore, dialogic interactions between IEL and IHRL have had both their drawbacks ${ }^{91}$ and opportunities; ${ }^{92}$ however, it must be noted that both 'regimes' formally converge into the state-centred paradigm as obligations to respect, protect and fulfil human rights and the environment are borne by the state, despite the fact that both conceive - predominantly in academic literature - non-state actors in general and business enterprises in particular, as fundamental elements for understanding the reasons behind environmental degradation and human rights violations. Which begs the burning question of the necessity, if any, of the paradigm's formal contestation under international law.

Perhaps, acknowledging the commonalities linked to modulating the freedom of action of subjects based on elements of power exertion, amounting to social and ecological distortions, might contribute to reshape the so-called 'fragmentation of international law', namely the 'loss of an overall perspective on the law'. ${ }^{93}$

After all, IHRL and IEL are regimes that appeal to alleged universal values or 'global concerns' upon which humanity is besought to respond. Thus, harnessing their 'hegemonic structure' vis-à-vis correcting power imbalances struck by MNCs through international legal obligations, might be an opportunity to solve a legal impasse by way of interaction and integration, ${ }^{94}$ which may be crystallized in a new BHRT.

91 DONALD, Kate. Human rights practice: a means to environmental ends? Oñati Journal of Emergent Socio-Legal Studies, v. 3, n. 5, p. 908-930, 2013. It is argued that human rights fall short in contributing to the extensive development of environmental law compliance mechanisms; in addition, human rights focus more on the remedy rather than preventive measures, as environmental law does.

92 KNOX, John. Human rights, environmental protection, and the sustainable development goals. Washington International Law Journal, v. 24 , n. 4, p. 517-536, 2015. p. 517. He argues that human rights law provides effective procedural obligations for states, more elements to balance diverse societal interests and more protection to vulnerable groups from environmental harms.

93 UNITED NATIONS INTERNATIONAL LAW COMMISSION. Fragmentation of international law: difficulties arising from the diversification and expansion of international law. Erik Castrén Institute of International Law and Human Rights, 2007. para. 8.

94 KOSKENNIEMI, Martti. Hegemonic regimes. In: YOUNG, Margaret (Ed.). Regime interaction in international law. United Kingdom: Cambridge University Press, 2011. p. 324.

\section{SOME STRATEGIES FOR CORPORATE ACCOUNTABILITY}

\subsection{Civil, criminal and human rights law versus MNCs: effective tools for environmental protection?}

Whenever a human right abuse linked to an environmental harm occurs between a private actor (a MNC) against another private actor (a victim or group of victims), the forum on which the case will be resolved depends on the jurisdictional rules of a specific legal system. ${ }^{95}$ This stems the possibility that proceedings can be filed either in a host or a home country. ${ }^{96}$

This apparent simplicity is superseded by the convoluted issue of 'fragmentation of jurisdiction', which is intimately linked to the nature of holding accountable a MNC. For instance, the headquarters, the legal incorporation, the shareholders, the operations, the workers and those affected by the operations, can all come from a different jurisdiction. ${ }^{97}$

This diversity obliges plaintiffs to be meticulous about selecting the type of recourse they should engage with. The options range from administrative, tort or criminal litigation against MNCs or their subsidiaries. However, finding proper redress in host states may entail several legal and procedural shortcomings. For instance, domestic legislation may not enshrine criminal or civil liability for legal persons; or the domestic judiciary might not be well-equipped for a highly complex task such as piercing a corporate veil; or it may be prone to hamper an independent trial; ${ }^{98}$ or even if victims were favoured with a positive domestic judgement, the defendant may not have assets or personnel in the host country to actually materialize the redress, as exemplified by Aguinda v. Chevron in Ecuador. ${ }^{99}$ These types of

95 BOYLE, Alan. Globalising environmental liability: the interplay of national and international law. Journal of Environmental Law, v. 17 , n. 1, p. 3-26, 2005.

96 BIRNIE, Patricia; BOYLE, Alan; REDGWELL, Catherine. International law and the environment. 3. ed. United Kingdom: Oxford University Press, 2009. p. 312.

97 CLAPHAM, Andrew. Human rights obligations of non-state actors. United Kingdom: Oxford University Press, 2006. p. 200.

98 LAGOUTTE, Stéphanie. New challenges facing states within the field of human rights and business. Nordic Journal of Human Rights, v. 33, n. 2, p. 158-180, 2015. p. 172.

99 KIMERLING, Judith. Remarks by Judith Kimerling. Proceedings of the Annual Meeting: american Society of International Law, v. 
shortcomings are constantly capitalized by big private companies, who are in a position to pay top law firms to effectively make use of substantive and procedural rules in their favour, thus sidestepping liability. ${ }^{100}$

These obstacles lead victims to pursue justice in MNCs' home states, like in the US, home of thousands of MNCs. ${ }^{101}$ There, victims are able to sue US companies under several statutes, including the most renowned, the Alien Tort Claim Statute (ATCA), an $18^{\text {th }}$ century statute that confers upon the Federal District Courts original jurisdiction over 'any civil action by an alien for a tort only committed in violation of the law of nations'. ${ }^{102}$

US jurisdiction provides victims a sense of due process, while giving them the chance of publicizing their case, ${ }^{103}$ which explains the urge of Burmese victims to use the ATCA against the oil giant Unocal, allegedly involved in human rights violations in the context of the construction of an oil pipeline. ${ }^{104}$ However, the Federal Court ruled that the corporations could not be held liable under international law, ${ }^{105}$ although the Ninth District Court of Appeals subsequently overturned that previous view. ${ }^{106}$ In the aftermath, this case along with others, like Wiwa v. Royal Dutch Petroleum, ${ }^{107}$ agreed

106, p. 416-419, 2012.

100 MCCONNELL, Lee. Establishing liability for multinational oil companies in parent/subsidiary relationships case note. Environmental Law Review, v. 16, n. 1, p. 50-59, 2014.

101 COCKBURN, Iain; SLAUGHTER, Matthew. The global location of biopharmaceutical knowledge activity: new findings, new questions. Innovation Policy and the Economy, v. 10, p. 129-157, 2010. In 2006, there were more that 2000 MNCs registered in the US alone. 102 CLAPHAM, Andrew. Human rights obligations of non-state actors. United Kingdom: Oxford University Press, 2006. p. 252.

103 KATUOKA, Saulius; DAILIDAITE, Monika. Responsibility of transnational corporations for human rights violations: deficiencies of international legal background and solutions offered by national and regional legal tools. Jurisprudencija, v. 19, n. 4, p. 13011316, 2012. p. 1309

104 RAMASASTRY, Anita. Corporate complicity: from Nuremberg to Rangoon: an examination of forced labor cases and their impact on the liability of multinational corporations Stefan A. Riesenfeld symposium 2001. Berkeley Journal of International Law, v. 20, n. 1, p. 91-159, 2002.

105 RAMASASTRY, Anita. Corporate complicity: from Nuremberg to Rangoon: an examination of forced labor cases and their impact on the liability of multinational corporations Stefan A. Riesenfeld symposium 2001. Berkeley Journal of International Law, v. 20, n. 1, p. 91-159, 2002. p. 137.

106 CLAPHAM, Andrew. Human rights obligations of non-state actors. United Kingdom: Oxford University Press, 2006. p. 256.

107 CENTER FOR CONSTITUTIONAL RIGHTS. Wiwa et al. v. royal dutch petroleum et al. Available in: <https://ccrjustice.org/ node/1505>. to settle the lawsuit out of court. ${ }^{108}$

In a related case, Kiobelv. Royal Dutch Petroleum have set precedents regarding dismissals based on the impossibility of extra-jurisdictional reach of US courts concerning alleged unlawful acts. ${ }^{109}$ Likewise, US Courts have repeatedly afforded the doctrine of forum non conveniens, which gives a court discretion to dismiss the case on the basis of having a better court to vent the action. ${ }^{110}$ According to several studies, dismissal on the grounds of this doctrine is typically outcome determinative - if the victims are unable to sue in U.S. courts, they are unable to recover for the violations of their rights. ${ }^{111}$

In some European jurisdictions, however, the argument of forum non conveniens might be less substantial for national courts, who have jurisdiction over those corporate defendants domiciled in the territory of EU Member States in light of the rules of jurisdiction under the so called 'Brussels system', composed by some provisions under the Regulation on Jurisdiction and the Recognition and Enforcement of Judgments in Civil and Commercial Matters. ${ }^{112}$ This is the case of England, where claimants of environmental nuisance, prompted by English parent companies or their subsidiaries, have been able to establish the English jurisdiction as the adequate one. ${ }^{113}$ However, cases that discuss the extent of the alleged damages and a proper redress therein are quite scarce, as the customary practice is to resort to

108 IROGBE, Kema. Global political economy and the power of multinational corporations. Journal of Third World Studies, v. 30, n. 2, p. 241, 2013.

109 SCHUTTER, Olivier De; SKINNER, Gwynne; MCCORQUODALE, Robert. The third pillar. access to judicial remedies for human rights violations by transnational business. International Corporate Accountability Roundtable, 2013. p. 5.

110 FOLEY SMITH, Erin. Right to remedies and the inconvenience of forum non conveniens: opening U.S. courts to victims of corporate human rights abuses. Columbia Journal of Law and Social Problems, v. 44, n. 2, p. 145-192, 2010.

111 FOLEY SMITH, Erin. Right to remedies and the inconvenience of forum non conveniens: opening U.S. courts to victims of corporate human rights abuses. Columbia Journal of Law and Social Problems, v. 44, n. 2, p. 145-192, 2010. p. 165.

112 MERINO BLANCO, Elena; PONTIN, Ben. Litigating extraterritorial nuisances under english common law and UK statute. Transnational Environmental Law, v. 6, n. 2, p. 285-308, 2017.

113 UNITED KINGDOM. England and Wales High Court. The bodo community and others $v$ shell petroleum development company of Nigeria Ltd. EWHC 1973, 2014.; UNITED KINGDOM. United Kingdom House of Lords. Connelly v. RTZ Plc. AC 854, 1998.; UNITED KINGDOM. United Kingdom House of Lords. Lubbe and Ors $v$. Cape Plc. WLR 1545, 2000. 
an out-of-court settlement. ${ }^{114}$ Furthermore, in what might be the worst case scenario from the perspective of claimants when pursuing remedies in the home state's jurisdiction, a judge might award the defendants indemnity costs borne by plaintiffs soon after not having been convinced in ascertaining responsibility, as it was the case in the Pedro Emiro Florez. Arroyo v. Equion Energia Limited, related to alleged environmental damages derived to deficient conditions of an Oil pipe in Colombia. ${ }^{115}$

Conversely, if the weapon of choice were to be international criminal law, users might be discouraged after grasping the two-folded challenge: environmental crimes are not a priority and corporations as such are not formal subjects. Usually, international criminal law 'delegates the criminal protection of the environment to the State parties to multilateral environmental treaties. The crimes thus prosecuted are, in fact, national crimes'. ${ }^{116}$ Also, the Rome Statute of the International Criminal Court provides limited 'relevance to the environment exclusively within the context of the core crimes falling under the jurisdiction of the International Criminal Court (ICC)'. ${ }^{117}$ In this vein, considerable attention was brought to the publication of a Policy Paper on Case Selection and Prioritization by the Office of the Prosecutor of the ICC in September 2016, to contemplate those crimes committed through, or resulting in, 'the destruction of the environment, the illegal exploitation of natural resources or the illegal dispossession of land'. However, despite this laudable development, 'it does not alter the current framework, as it merely sets out internal guidelines governing the exercise of prosecutorial discretion in the selection and prioritization of cases'. ${ }^{118}$

114 KRAMER, Xandra. UK court on tort litigation against transnational corporations: conflicts of laws. Available in: <http://conflictoflaws.net/2016/uk-court-on-tort-litigation-against-transnationalcorporations $/>$.

115 UNITED KINGDOM. England and Wales High Court. Pedro Emiro Florez Arroyo \& others v Equion Energia Limited fformerly BP exploration company (Colombia) limited]. EWHC 1699 (TCC), 2016.

116 MISTURA, Alessandra. Is there space for environmental crimes under international criminal law?: the impact of the office of the prosecutor policy paper on case selection and prioritization on the current legal framework. Columbia Journal of Environmental Law, v. 43, n. 1, p. 181-226, 2018.

117 MISTURA, Alessandra. Is there space for environmental crimes under international criminal law?: the impact of the office of the prosecutor policy paper on case selection and prioritization on the current legal framework. Columbia Journal of Environmental Law, v. 43, n. 1, p. 181-226, 2018. p. 214.

118 MISTURA, Alessandra. Is there space for environmental crimes under international criminal law?: the impact of the office of
Moreover, the Rome Statute excludes legal persons from its scope, on the basis that corporations do not have 'a body to kick and soul to damn', ${ }^{119}$ and that there is no global consensus on the standard for corporate liability. ${ }^{120}$ Even though this forum does not have jurisdiction, it can prosecute individuals associated to negligent businesses.

Another option of remedy has been recurring to regional human rights bodies. Even if these bodies are deemed as one of the few alternatives to litigate human rights violations linked to environmental damages - once domestic remedies are exhausted, 'they are not generally enforcing [IEL]'. ${ }^{21}$ The European (ECHR) and Inter-American (IACtHR) Court of Human Rights for instance, have been less willing to hear cases where environmental issues go beyond immediate human well-being?. ${ }^{122}$

In that sense, procedural rights related to the environment have been safeguarded before the IACtHR in cases related to indigenous peoples ${ }^{123}$ and not-indigenous peoples, ${ }^{124}$ stressing an 'undeniable link between the protection of the environment and the enjoyment of other human rights'. ${ }^{125}$ 'This inter-linkage has also been pointed out in the jurisprudence of the ECHR, by

the prosecutor policy paper on case selection and prioritization on the current legal framework. Columbia Journal of Environmental Law, v. 43, n. 1, p. 181-226, 2018. p. 225.

119 VAN DER WILT, Harmen. Corporate criminal responsibility for international crimes: exploring the possibilities. Chinese Journal of International Law, v. 12, n. 1, p. 43-77, 2013.

120 KREMNITZER, Mordechai. A possible case for imposing criminal liability on corporations in international criminal law. Journal of International Criminal Justice, v. 8, n. 3, p. 909-918, 2010.

121 SHELTON, Dinah. Legitimate and Necessary: Adjudicating Human Rights Violations Related to Activities Causing Environmental Harm or Risk. Journal of Human Rights and the Environment, v. 6, n. 2, p. 139-155, 2015.

122 SHELTON, Dinah. Legitimate and Necessary: Adjudicating Human Rights Violations Related to Activities Causing Environmental Harm or Risk. Journal of Human Rights and the Environment, v. 6, n. 2, p. 150, 2015.

123 INTER-AMERICAN COURT OF HUMAN RIGHTS. Saramaka people v suriname: preliminary objections, merits, reparations, and costs). IACtHR Series C No. 172, 2007. para. 147; INTERAMERICAN COURT OF HUMAN RIGHTS. Kichwa indigenous people of Sarayaku v. Ecuador: merits and reparations. IACtHR Series C, n. 245, 2012. para. 183.

124 INTER-AMERICAN COURT OF HUMAN RIGHTS. Claude-Reyes et al v Chile: merits, reparations and costs. IACtHR Series C, n. 15, 2006. para. 73 .

125 INTER-AMERICAN COURT OF HUMAN RIGHTS. Kawas-Fernández v. Honduras: merits, reparations and costs. IACtHR Series C, n. 196, 2009. para. 148. 
underscoring the environmental dimension of the right to respect for privacy and family. ${ }^{126}$ The IACtHR has a 'collective/public interest-oriented approach to the adjudication of environmental complaints', ${ }^{127}$ a feature not very developed in the ECHR.

Despite this increasingly progressive stance on connecting the environment and human rights, the state-centred paradigm is still grained in the aforementioned bodies. Jurisprudence of said bodies stresses that the state assumes the obligation to prevent, investigate and punish human rights violations as due diligence, and failing to do this may lead to states' international responsibility, even if the wrongful act was committed by a private actor. ${ }^{128}$ This deferral on the basis of lack of jurisdiction is the main obstacle to render MNCs liable before human rights bodies. ${ }^{129}$

\subsection{UN initiatives}

In 1977, an Intergovernmental Working Group on a Code of Conduct was appointed by the UN Commission on Transnational Corporations to elaborate the UNCCTC. This work started with several disagreements, chiefly whether the treaty had to be binding or not. ${ }^{130}$ However, they did agree on environmental protections in its first round of negotiations, although the content of the instrument is rather broad and exhortatory. ${ }^{131}$ Overall, the UNCCTC ensured that MNCs pro-

126 EUROPEAN COURT OF HUMAN RIGHTS. López Ostrav Spain: merits and just satisfaction. ECHR App no 16798/90, 1994.; EUROPEAN COURT OF HUMAN RIGHTS. Fadeyeva v Russian Federation: judgment, merits and just satisfaction. ECHR App No 55723/00, 2005.; EUROPEAN COURT OF HUMAN RIGHTS. Guerra and others. $v$ Italy: judgment, merits and just satisfaction. ECHR App No 14967/89, 1998.

127 PAVONI, Riccardo. Environmental jurisprudence of the european and inter-american courts of human rights. In: BOER, Ben (Ed.). Environmental law dimensions of human rights. United Kingdom: Oxford University Press, 2015. p. 106.

128 INTER-AMERICAN COURT OF HUMAN RIGHTS. Velásquez-Rodríguez v Honduras: merits. IACtHR Series C, n. 04, 1988. para. 72; INTER-AMERICAN COURT OF HUMAN RIGHTS. International responsibility for the promulgation of laws in violation of the convention: advisory opinion. IACtHR OC-14/94, 1994. para. 56.

129 KHOURY, Stéfanie. Transnational corporations and the european court of human rights: reflexions on the indirect and direct approaches to accountability. Oñati Journal of Emergent Socio-Legal Studies, v. 4, n. 1, p. 68-110, 2010.

130 SAUVANT, Karl. The negotiations of the United Nations code of conduct on transnational corporations: experience and lessons learned. The Journal of World Investment \& Trade, v. 16, p. 11-87, 2015.

131 MORGERA, Elisa. Corporate accountability in international envi- vide a 'stable, predictable, and transparent framework to [strength] international investments; and to help minimize [their] negative effects'. ${ }^{132}$

By the beginning of the 1990s, it was clear that none of the participants were interested in continuing with the negotiations, probably due to the shift of priorities towards the encouragement of FDI, ${ }^{133}$ or because its all-encompassing approach arose suspicion around MNCs who refused to be bound by international standards, heralding the failure of the UNCCTC in $1992 .{ }^{134}$

In August 2003, the UN Sub-Commission for the Promotion and Protection of Human Rights adopted the Norms, a novel and comprehensive list of human rights standards for MNCs. ${ }^{135}$ The Norms comprise a reference to numerous international legal instruments, namely human rights and environmental treaties, such as the Convention on Biological Diversity (CBD) and the Rio Declaration. ${ }^{136}$

Such standards, however, were criticized due to the impracticality behind uniformly applying them across different countries with diverse legal traditions and realities; and, for including rights that were not still recognized by all states. ${ }^{137}$ For instance, the Norms envisage that MNCs shall conduct their operations in accordance to national and international environmental and human rights regulations. ${ }^{138}$

In spite of its ambitious and stringent language, the

ronmental law. United Kingdom: Oxford University Press, 2009. p. 84. 132 MORGERA, Elisa. Corporate accountability in international environmental law. United Kingdom: Oxford University Press, 2009. p. 80. 133 SAUVANT, Karl. The negotiations of the United Nations code of conduct on transnational corporations: experience and lessons learned. The Journal of World Investment \& Trade, v. 16, p. 11-87, p. $55,2015$.

134 CARASCO, Emily; SINGH, Jang. Towards holding transnational corporations responsible for human rights. European Business Review, v. 22, n. 4, p. 432-445, 2010.

135 GELFAND, Jacob. The lack of enforcement in the united nations draft norms: benefit or disadvantage?. In: SCHUTTER, Olivier De (Ed.). Transnational corporations and human rights. Hart Pub, 2006. p. 314.

136 UNITED NATIONS. Norms on the responsibilities of transnational corporations and other business enterprises with regard to buman rights. E/CN4/Sub2/2003/12/Rev2, 2003. p. 2.

137 GELFAND, Jacob. The lack of enforcement in the united nations draft norms: benefit or disadvantage?. In: SCHUTTER, Olivier De (Ed.). Transnational corporations and human rights. Hart Pub, 2006. p. 316-318.

138 UNITED NATIONS. Norms on the responsibilities of transnational corporations and other business enterprises with regard to buman rights. E/CN4/Sub2/2003/12/Rev2, 2003. 
Norms were not accepted by the Commission on $\mathrm{Hu}-$ man Rights, ${ }^{139}$ and only reached 'a level of expert legitimacy, but no political endorsement'. ${ }^{140}$ However, its merit rests on its potential to convey its positive conceptual array onto other regimes of corporate environmental and human rights standard-setting, ${ }^{141}$ like the UNGP and the BHRT.

As a strategy to fill the void left by hard-law approaches rehearsed in the past, the UN decided to give the 'partnership approach' a chance, launching the GC as a soft-law strategy for 'leveraging the platform' of large corporations and encouraging socially responsible corporate behaviour. ${ }^{142}$ The GC, just like the Norms, covers broad and flexible principles that hinge upon existing UN documents, ${ }^{143}$ namely the UDHR and the Rio Declaration.

However, the GC was not without its critics, who attributed its voluntary nature to a lack of responsiveness from some MNCs to civil society's claims regarding corporate's human rights abuses; ${ }^{144}$ and also questioned those MNCs' continuance in the initiative. ${ }^{145}$ Overall, critics perceive the GC as 'long on promises, short on performance, and mostly silent on transparency and objective reporting, ${ }^{146}$ however, it does require from

139 WEISSBRODT, David. Human rights standards concerning transnational corporations and other business entities. Minnesota Journal of International Law, v. 23, n. 2, p. 135-171, 2014. p. 165.

140 MORGERA, Elisa. Benefit-sharing as a bridge between the environmental and human rights accountability of multinational corporations. In: Ben Boer (Ed.). Environmental law dimensions of human rights. United Kingdom: Oxford University Press, 2015. p. 46.

141 MORGERA, Elisa. Benefit-sharing as a bridge between the environmental and human rights accountability of multinational corporations. In: Ben Boer (Ed.). Environmental law dimensions of human rights. United Kingdom: Oxford University Press, 2015. p. 46; WEISSBRODT, David. Human rights standards concerning transnational corporations and other business entities. Minnesota Journal of International Law, v. 23, n. 2, p. 135-171, 2014. p. 167.

142 GHAFELE BASHI, Roya; MERCER, Angus. "Not starting in sixth gear". UC Davis Journal of International Law and Policy, v. 17, n. 1, p. 41-61, 2011. p. 41-61.

143 MORGERA, Elisa. The UN and corporate environmental responsibility: between international regulation and partnerships. Review of European Community and International Environmental Law, v. 15, n. 1 p. 93-109, 2006. p. 99.

144 KAMMINGA, Menno. Company responses to human rights reports: an empirical analysis. Business and Human Rights Journal, v. 1, n. 1, p. 95-110, 2016.

145 SETHI, S. Prakash; SCHEPERS, Donald H. United Nations global compact: the promise-performance gap. Journal of Business Ethics, v. 122, n. 2, p. 193-208, 2013. p. 193-208.

146 SETHI, S. Prakash; SCHEPERS, Donald H. United Nations global compact: the promise-performance gap. Journal of Business Ethics, v. 122, n. 2, p. 193-208, 2013. p. 201. companies the implementation of measures based on the precautionary approach ${ }^{147}$ and also have a procedure to handle egregious abuse of its principles, including severe environmental damage. ${ }^{148}$ Thus, it could be said that the climate of divisiveness around this instrument may indicate that further and concrete results are yet to be seen.

\subsection{The UNGP}

John Ruggie, the SRSG, made it very clear from the beginning of his mandate, that he was going to leave behind the approach taken in the Norms - who deemed them as a 'distraction', and adopted a 'principled pragmatism' instead, whose legitimacy was reached by 'consulting with a wide range of stakeholders [while] keeping businesses and government "on side"..149

The result of the SRSG's acclaimed mandate was the design of the UNFBHR and the UNGP to implement it. Comprising 31 principles and corresponding commentaries, the UNGP clarify legal and policy implications. ${ }^{150}$ They apply to all states and all business enterprises, ${ }^{151}$ and encompass all internationally recognized rights, being the floor the International Bill of Human Rights and the principles set out in the ILO's Declaration on Fundamental Principles and Rights at Work. ${ }^{152}$ Moreover, they rest upon three pillars designed for states and businesses who are called to flesh-out mechanisms to protect individuals from human rights abuses across the world. The first one is the duty of states to integrally protect human rights, the second entails the corporate's

147 MORGERA, Elisa. Multinational corporations and international environmental law. In: ALAM, Shawkat et al. (Ed.). Routledge handbook of international environmental law. Routledge, 2015. p. 198.

148 MORGERA, Elisa. From corporate social responsibility to accountability mechanisms. In: DUPUY, Pierre-Marie; VIÑUALES, Jorge (Ed.). Harnessing foreign investment to promote environmental protection. United Kingdom: Cambridge University Press, 2013. p. 338.

149 SIMONS, Penelope. International law's invisible hand and the future of corporate accountability for violations of human rights. Journal of Human Rights and the Environment, v. 3, n. 1, p. 5-43, 2012.

150 RUGGIE, John. Report of the special representative of the secretary general on the issue of human rights and transnational corporations and other business enterprises. Report submitted before session 17 of the human rights council. A/HRC/17/31, 2011.

151 RUGGIE, John. A UN business and buman rights treaty?. Available in: <https://www.hks.harvard.edu/m-rcbg/CSRI/UNBusinessandHumanRights'Treaty.pdf $>$.

152 RUGGIE, John. Report of the special representative of the secretary general on the issue of buman rights and transnational corporations and other business enterprises. Report submitted before session 17 of the human rights council. A/HRC/17/31, 2011. p. 13. 
application of due diligence aimed at respecting human rights, and the third pillar underpins the necessity of effective remedies for human rights victims. ${ }^{153}$

It is worth noticing that the second pillar within the UNGP relies on corporate due diligence - a widely applied concept in environmental protection contexts - which involves '(i) impact assessment; (ii) stakeholder involvement in decision-making; and (iii) life-cycle management'. ${ }^{154}$ Nonetheless, there is no evidence of synergies between the UNGP and principles or instruments of IEL. ${ }^{155}$

The omnipresent nature of the UNGP is undeniable; they are being used by governments, intergovernmental organizations, human rights advocate groups, and foremost, business themselves. ${ }^{156}$ For instance, the HRC enacted two ${ }^{157}$ resolutions on human rights and the environment, explicitly pointing out the importance of the UNGP. Furthermore, in the Kalina and Lokono Peoples v. Suriname case, the IACtHR took note of the UNGP, reiterating the obligation of states to 'protect against human rights abuses within their territory and/or jurisdiction by third parties, including business enterprises'. ${ }^{158}$ Additionally, the UN Committee on Economic, Social and Cultural Rights addressed the role of businesses in the adverse impacts on human rights through a General Comment, whereby the UNGP was considered a pivotal document. ${ }^{159}$

The UNGP have been received with enthusiasm by some, ${ }^{160}$ arguing a global consensus and momentum

153 RUGGIE, John. Just business: multinational corporations and human rights. W. W Norton \& Company, 2013. p. 7.

154 MORGERA, Elisa. Benefit-sharing as a bridge between the environmental and human rights accountability of multinational corporations. In: Ben Boer (Ed.). Environmental law dimensions of human rights. United Kingdom: Oxford University Press, 2015. p. 44.

155 MORGERA, Elisa. Multinational corporations and international environmental law. In: ALAM, Shawkat et al. (Ed.). Routledge handbook of international environmental law. Routledge, 2015. p. 204.

156 RUGGIE, John. A UN business and human rights treaty?. Available in: <https://www.hks.harvard.edu/m-rcbg/CSRI/UNBusinessandHumanRights'Treaty.pdf $>$.

157 UNITED NATIONS HUMAN RIGHTS COUNCIL. Human rights and the environment. UN. Doc. A/HRC/RES/19/10, 2012.; UNITED NATIONS HUMAN RIGHTS COUNCIL. Human rights and the environment. UN Doc. A/HRC/RES/25/21, 2014.

158 INTER-AMERICAN COURT OF HUMAN RIGHTS. Kalina and Lokono peoples v Suriname: merits, reparations and costs). IACtHR Series C, n. 309, 2015. para. 224.

159 UN COMMITTEE ON ECONOMIC, SOCIAL AND CULTURAL RIGHTS. General comment no. 24 on State obligations under the international covenant on economic, social and cultural rights in the context of business activities. Treaty Body General Comment E/C.12/GC/24, 2017. para 2. 160 SECK, Sara. Canadian mining internationally and the UN as its major strength, and with scepticism by others, ${ }^{161}$ underlining an ontological flaw entrenched to their voluntary nature. Overall, it seems that the common agreement is that a follow-up of the implementation of the UNGPs shall be undertaken. In this vein, the HRC established a Working Group on Business and Human Rights (WGBHR), ${ }^{162}$ who stressed that information regarding state protection of human rights from companies is lacking due to the novelty of integrating the UNGP onto domestic legislation, therefore the need of a future complete assessment. ${ }^{163}$ This reaffirms Ruggie's description of the essence of the UNGP as 'the end of the beginning. ${ }^{164}$

\section{Drafting the BHRT}

The proposal to elaborate a BHRT under the auspices of the HRC, led by Ecuador and South Africa, was passed with 20 votes in favour, 14 against and 13 abstentions, ${ }^{165}$ a different result to that of the unanimously endorsed UNGP just four years before, indicating a contentious future, specially around sensitive

guiding principles for business and human rights. Canadian Yearbook of International Law, v. 49, p. 51-116, 2011. p. 51-116; ANAYA, James. Statement by Professor James Anaya special Rrapporteur on the rights of indigenous peoples. FORUM ON BUSINESS AND HUMAN RIGHTS, 2012. Available in: <http://unsr.jamesanaya.org/ statements/forum-on-business-and-human-rights-2012-statementby-professor-james-anaya>.

161 WETTSTEIN, Florian. Normativity, ethics, and the UN gGuiding principles on business and human rights: a critical assessment. Journal of Human Rights, v. 14, n. 2, p. 162-182, 2015; LÓPEZ, Carlos. The "ruggie process": from legal obligations to corporate social responsibility? In: DEVA, Surya; BILCHITZ, David (Ed.). Human rights obligations of business. Cambridge University Press, 2013.; BLITT, Robert. Beyond Ruggie's guiding principles on business and human rights: charting an embracive approach to corporate human rights compliance. Texas International Law Journal, v. 48, n. 1, p. 33-62, 2012.

162 UNITED NATIONS HUMAN RIGHTS COUNCIL. Human rights and transnational corporations and other business enterprises. A/ HRC/RES/17/4, 2011. para. 11.

163 WORKING GROUP ON THE ISSUE OF HUMAN RIGHTS AND TRANSNATIONAL CORPORATIONS AND OTHER BUSINESS ENTERPRISES. Report of the working group on the issue of buman rights and transnational corporations and other business enterprises. UN Doc. A/70/216, 2015. para 3.

164 RUGGIE, John. Just business: multinational corporations and human rights. W. W Norton \& Company, 2013. p. 204.

165 UNITED NATIONS HUMAN RIGHTS COUNCIL. Elaboration of an international legally binding instrument on transnational corporations and other business enterprises with respect to buman rights. UN. Doc. A/ HRC/RES/26/9, 2014. 
issues - like direct obligations on MNCs. Overall, its main foreseeable risk, if negotiations are successful, is a 'diluted standards' type of instrument. ${ }^{166}$

Except for China, states that voted against the proposition are the ones with the largest and most influential MNCs in the world. This is of particular interest since the resolution is circumscribed to the regulation of MNCs exclusively, leaving national corporations out of its scope. ${ }^{167}$ Another sign of early contention is that countries who did not support the BHRT, did sponsor a resolution on the extension for three more years of the mandate of the WGBHR, whose main task is the study of the implementation of the UNGP ${ }^{168}$.

Bearing in mind that the idea of a BHRT is not a new one, this revised hard-law approach, advocated by an important number of NGOs, scholars and states alike, ${ }^{169}$ might be a political sentiment of restlessness, probably stirred by the modest results of past initiatives - a sentiment that seeks to level the playing field through a diplomatic process. However, what is already obvious is that this open-ended process will take several years of negotiations until a treaty is finally adopted, which is a fair point from the UNGP's advocates, who strive for its implementation as an interim pragmatic measure. ${ }^{170}$

The HRC in its Resolution 26/9, decided that the first two sessions of the OEIGWG ought to be dedicated to conduct 'constructive deliberations on the content, scope, nature and form of the future international instrument ${ }^{171}$ and recommended that relevant stake-

166 NOLAN, Justine. A business and human rights treaty. In: BAUMANN-PAULY, Dorothée; NOLAN, Justine (Ed.). Business and human rights: from principles to practice. Routledge, 2016. p. 72. 167 GANESAN, Arvid. Towards a business and human rights treaty?. In: BAUMANN-PAULY, Dorothée; NOLAN, Justine (Ed.). Business and human rights: from principles to practice. Routledge, 2016. p. 74.

168 UNITED NATIONS HUMAN RIGHTS COUNCIL. Human rights and transnational corporations and other business enterprises. UN. Doc. A/HRC/RES/26/22, 2014. para. 10.

169 LAGOUTTE, Stéphanie. New challenges facing states within the field of human rights and business. Nordic Journal of Human Rights, v. 33, n. 2, p. 158-180, 2015. p. 178.

170 RUGGIE, John. The past as prologue?: a moment of truth for UN business and human rights treaty. Available in: < https://www. hks.harvard.edu/m-rcbg/CSRI/Treaty_Final.pdf >. p. 6.

171 UNITED NATIONS HUMAN RIGHTS COUNCIL. Elaboration of an international legally binding instrument on transnational corporations and other business enterprises with respect to buman rights. UN. Doc. A/ HRC/RES/26/9, 2014. para. 2. -holders should submit inputs on this regard. ${ }^{172}$ In this vein, the OEIGWG, chaired by the representative of Ecuador, had conveyed three sessions up to date in July 2015, October $2016^{173}$ and October $2017^{174}$ respectively. In all sessions, the presence of states, intergovernmental organizations and NGOs that supported the creation of the group were welcomed and acknowledged, ${ }^{175}$ who actively participated in shaping the travaux préparatories ${ }^{176}$ of the proto-treaty. However, the complete absence of the United States and the timid presence of the European Union did not go unnoticed. ${ }^{177}$

Discussions were generally conveyed by general statements from state's delegates, which highlighted the inter-linkage between the environment and human rights, such as the delegation of Algeria, who stated that 'environmental degradation [and] dumping of toxic wastes [...] by [MNCs], affect, marginalise and impoverish groups disproportionally and exacerbate existing human rights concerns'; ${ }^{\prime}{ }^{178}$ a statement echoed by Indonesia ${ }^{179}$ and China, ${ }^{180}$ who noted that despite the leading

172 UNITED NATIONS HUMAN RIGHTS COUNCIL. Elaboration of an international legally binding instrument on transnational corporations and other business enterprises with respect to human rights. UN. Doc. A/ HRC/RES/26/9, 2014. para. 2.

173 UNITED NATIONS HUMAN RIGHTS COUNCIL. Report on the second session of the open-ended intergovernmental working group on transnational corporations and other business enterprises with respect to buman rights. A/HRC/34/47, 2017.

174 UNITED NATIONS HUMAN RIGHTS COUNCIL. Report on the third session of the open-ended intergovernmental working group on transnational corporations and other business enterprises with respect to buman rights. A/HRC/37/67, 2018.

175 UNITED NATIONS HUMAN RIGHTS COUNCIL. Report on the first session of the open-ended intergovernmental working group on transnational corporations and other business enterprises with respect to human rights, with the mandate of elaborating an international legally binding instrument. A/HRC/31/50, 2016. para. 6-10.

176 SHAW, Malcolm. International law. 6. ed. United Kingdom: Cambridge University Press, 2008. p. 935.

177 SHAW, Malcolm. International law. 6. ed. United Kingdom: Cambridge University Press, 2008. p. 39.

178 MOHAMADIEH, Kinda; URIBE, Daniel. Business and buman rights: commencing discussions on a legally binding instrument. South Centre Bulletin. Available in: <http://www.southcentre.int/ wp-content/uploads/2015/11/SB87-88_EN.pdf>. p. 6.

179 INDONESIAN DELEGATION. Statement by Indonesian delegation at the 1st session of the open-ended intergovernmental working group on transnational corporations and other business enterprises with respect to buman rights, 2015. Available in: <http://www.ohchr.org/Documents/HRBodies/HRCouncil/WGTransCorp/Session1/GeneralComments/ States/Indonesia1.pdf>. p. 2.

180 MOHAMADIEH, Kinda; URIBE, Daniel. Business and human rights: commencing discussions on a legally binding instrument. South Centre Bulletin. Available in: <http://www.southcentre.int/ wp-content/uploads/2015/11/SB87-88_EN.pdf>.p. 7. 
role of MNCs in global economic development, they also could injure human rights and the environment, which is why the inclusion of these issues in tandem with development are important.

NGOs' representatives also made numerous and relevant remarks about the importance of the environment, asserting that depletion of natural resources had an impact on the right to self-determination and an adequate standard of living, ${ }^{181}$ while positing the need for an international court on climate issues. ${ }^{182}$ In these lines, some delegations encouraged the inclusion of environmental principles, like the use of the best technology, polluter-pay principles (PPP) and FPIC; while at the same time highlighted the interdependence and indivisibility of human rights. ${ }^{183}$ South Africa for instance, encouraged the inclusion of effective remedies for environmental damage. ${ }^{184}$

During the three sessions, several panels of discussion were organized, each of which addressed core elements of the treaty. ${ }^{185}$ Thus, the analysis of the negotiations will be narrowed as to only include the topics related to direct obligations of MNCs in the context of environmental damage linked to human rights violations. The examination will be based on the travaux préparatoires of the treaty's drafting process, including the official reports of the three sessions, the document

181 UNITED NATIONS HUMAN RIGHTS COUNCIL. Report on the first session of the open-ended intergovernmental working group on transnational corporations and other business enterprises with respect to buman rights, with the mandate of elaborating an international legally binding instrument. A/HRC/31/50, 2016. para. 32.

182 UNITED NATIONS HUMAN RIGHTS COUNCIL. Report on the third session of the open-ended intergovernmental working group on transnational corporations and other business enterprises with respect to buman rights. A/HRC/37/67, 2018. para. 23.

183 UNITED NATIONS HUMAN RIGHTS COUNCIL. Report on the third session of the open-ended intergovernmental working group on transnational corporations and other business enterprises with respect to buman rights. A/HRC/37/67, 2018. para. 23.

184 SOUTH AFRICAN DELEGATION. Opening statement delivered by South Africa. Available in: <http://www.ohchr.org/Documents/HRBodies/HRCouncil/WGTransCorp/Session1/SOUTHAFRICAS_Opening_StatementbyAmbMinty_Panel1.pdf $>$. p. 3 .

185 UNITED NATIONS HUMAN RIGHTS COUNCIL. Report on the first session of the open-ended intergovernmental working group on transnational corporations and other business enterprises with respect to human rights, with the mandate of elaborating an international legally binding instrument. A/HRC/31/50, 2016. para. 2. Topics ranged during the last three sessions can be summarized as follows: general architecture of the international legally binding instrument; principles to be incorporated; scope of application; general obligations; responsibility and liability; access to justice, effective remedy and international cooperation. that sets out the elements for the draft, participants' submissions and non-official bulletins.

\subsection{Principles of the new Treaty}

During all the sessions, discussions began to stir on issues related to the principles that should be rooted in the treaty via oral addresses from some state delegations, legal experts and NGOs. However, most contributions touched upon a myriad of issues that do not fit neatly into the definition of principles as such, like the type of corporations that should be regulated, ${ }^{186}$ or the range of human rights that should be protected. ${ }^{187}$

Additionally, the anchoring of the principles within the treaty, which would allow to understand the interpretation of the context of the treaty, and the potential crystallization of currently recognized principles of IEL and their inter-play with general principles of international law, was largely obviated in the official report of the first session, and marginally touched upon in the subsequent two sessions, an aspect that is mirrored in the 'elements of the BHRT' document, where some wide-ranging principles were laid down, ${ }^{188}$ none of them referred to protecting the environment.

Some states, for instance, recommended that the principles should be included as an operative part of the instrument in order to facilitate its implementation, ${ }^{189} \mathrm{a}$ perspective shared by Ecuador, who in addition stated that hierarchies among principles should be averted. ${ }^{190}$

186 UNITED NATIONS HUMAN RIGHTS COUNCIL. Report on the first session of the open-ended intergovernmental working group on transnational corporations and other business enterprises with respect to buman rights, with the mandate of elaborating an international legally binding instrument. A/HRC/31/50, 2016. para. 44.

187 UNITED NATIONS HUMAN RIGHTS COUNCIL. Report on the first session of the open-ended intergovernmental working group on transnational corporations and other business enterprises with respect to buman rights, with the mandate of elaborating an international legally binding instrument. A/HRC/31/50, 2016. para. 46.

188 CHAIRMANSHIP OF THE OEIGWG. Elements for the draft legally binding instrument on transnational corporations and other business enterprises with respect to human rights, 2018. Available in: <https://www. ohchr.org/Documents/HRBodies/HRCouncil/WGTransCorp/ Session3/LegallyBindingInstrumentTNCs_OBEs.pdf>. p. 3 .

189 BOLIVIAN DELEGATION. Panel I: principios, conceptos y elementos, 2015. Available in: <http://www.ohchr.org/Documents/HRBodies/HRCouncil/WGTransCorp/Session1/Panel1/ States/BOLIVIA_PLURINATIOANL_STATE_OF.pdf $>$.

190 ECUADORIAN DELEGATION. Panel II: ámbito de aplicación de un instrumento prospectivo: alcance del instrumento; empresas transnacionales y otras empresas comerciales, conceptos y naturaleza jurídica en el derecho internacional, 2015. Available 
Some references were made with regards to the importance of expressly mentioning the principles within the future treaty in order to avoid erroneous interpretations or unnecessary legal voids. ${ }^{191}$ Contrariwise, it was also stressed that the principles should be placed in the preamble of the treaty and reflected in the treaty provisions. ${ }^{192}$

Principles, on this regard, may have three entwined purposes: the first one is to interpret the treaty as a whole during its implementation; ${ }^{193}$ secondly, to interpret it in the context of legal recourse before a compliance mechanism set in the treaty or by any other international adjudicative body; and thirdly, to guide and determine the scope and the wording of specific provisions.

Principles steering a treaty towards a coherent body of law have been already rehearsed in international environmental treaties, namely the United Nations Framework Climate Change Convention (UNFCCC), where principles like the 'common but differentiated responsibilities and respective capabilities', precaution-prevention and sustainable development have been drawn in an explicit article therein and have been accommodated all through the Convention's provisions. ${ }^{194}$ A shared feature with the CBD, where the principle of prevention of transboundary environmental harm is stressed. ${ }^{195}$

Principles of IEL have been developed by vast, diverse and even fragmented types of national and international instruments, ${ }^{196}$ demonstrating the key role

in: <http://www.ohchr.org/Documents/HRBodies/HRCouncil/ WGTransCorp/Session1/Panel2/States/ECUADORStatementOEIWG-PanelII.pdf>. p. 4.

191 CUBAN DELEGATION. Panel I: principios para un instrumento jurídicamente vinculante sobre corporación transnacionales y otros empresas en relación con los derechos humanos, 2015. Available in: <http://www.ohchr.org/Documents/HRBodies/HRCouncil/WGTransCorp/Session1/Panel1/States/CUBA.pdf>. p. 2.

192 MCCORQUODALE, Robert. Principles for an internationally legally binding instrument on TNC and other business enterprises with respect to human rights. Available in: <http://www.ohchr.org/Documents/ HRBodies/HRCouncil/WGTransCorp/Session1/McCorquodaleIGWGPanel060715.pdf>.

193 UNITED NATIONS. Vienna convention on the law of treaties (1969). New York: Treaty Series, v. 1155, n. 18232, 1987. p. 331.

194 UNITED NATIONS. United Nations framework convention on climate change. FCC/INFORMAL/84/Rev1, 1992. art. 3.

195 UNITED NATIONS. United Nations conference on environment and development: convention on biological diversity. International Legal Materials, v. 31, n. 4, p. 818-841, 1992.

196 SANDS, Philippe. Principles of international environmental law. 2. ed. Cambridge University Press, 2003. p. 169. that plays soft-law at embedding principles, such as the Rio Declaration, greatly endorsed by states ${ }^{197}$ and further included in several treaties. Thus, if environmental principles are discussed, they will serve as an authoritative way to resolve ambiguities, fill in gaps ${ }^{198}$ codify and progressively develop ${ }^{199}$ the law that is being resolved by the treaty.

Outlining general principles as an avenue to provide evidence of opinio juris and legitimacy, ${ }^{200}$ is not only confined to the realms of environmental law, but it is also reflected in the process of law making of the international human rights regime. ${ }^{201}$

Thus, placing different types of principles within the new treaty is likely to be the approach opted by some states and NGOs. However, written and oral contributions during the sessions have been characterised of being significantly imprecise and almost figurative, thus rendering it difficult to predict how exactly those invoked principles would be introduced into the text or how they would shape its content. Still, the fact that some participants are willing to address the challenges that the treaty presupposes by means of IEL principles, is a step forward towards a clarification of the extent of those principles in the context of corporate accountability.

For instance, the precautionary principle was specifically invoked during the first session - although in an indeterminate manner, by the delegation of Ecuador ${ }^{202}$ and several international NGOs, ${ }^{203}$ suggesting that sta-

197 BIRNIE, Patricia; BOYLE, Alan; REDGWELL, Catherine. International law and the environment. 3. ed. United Kingdom: Oxford University Press, 2009. p. 27.

198 SHELTON, Dinah. Normative hierarchy in international law. The American Journal of International Law, v. 100, n. 2, p. 291-323, 2006. 199 BIRNIE, Patricia; BOYLE, Alan; REDGWELL, Catherine. International law and the environment. 3. ed. United Kingdom: Oxford University Press, 2009. p. 30.

200 BOYLE, Alan; CHINKIN, Christine. The making of international law. United Kingdom: Oxford University Press, 2007. p. 224.

201 BILCHITZ, David. The necessity for a business and human rights treaty. Business and Human Rights Journal, v. 1, n. 2, p. 203-227, 2016.

202 ECUADORIAN DELEGATION. Panel II: ámbito de aplicación de un instrumento prospectivo: alcance del instrumento; empresas transnacionales y otras empresas comerciales, conceptos y naturaleza jurídica en el derecho internacional, 2015. Available in: <http://www.ohchr.org/Documents/HRBodies/HRCouncil/ WGTransCorp/Session1/Panel2/States/ECUADORStatementOEIWG-PanelII.pdf>. p. 4.

203 FRIENDS OF THE EARTH INTERNATIONAL. Written statement submitted by friends of the earth international. OEIWG, 2015. p. 3; TOXIC WATCH ALLIANCE. Proposals for legally enforceable 
tes should refrain from authorizing, promoting or facilitating the operations of MNCs when the likelihood of an impairment of human rights and the environment is extant.

Said formulation poses a number of questions regarding the implications of how the precautionary principle will be developed, essentially because the scope of the definition of the principle under international law is still unclear, ${ }^{204}$ and secondly because the proposals, as were submitted, tend to overlap the principle of prevention and precaution, a conceptual slip that potentially could become a bottleneck for future discussions.

Though, what it is clear is that the stakeholders' proposals do suggest a 'strong' interpretation of the principle, analogous to that of the World Charter for Nature, which envisages stymieing the activities which are likely to cause irreversible damage to nature or to recede the activities if a probable adverse effect to the environment is not fully understood. ${ }^{205}$

Moreover, it opens the question on who exactly is providing the evidence to determine whether the operations are innocuous to human rights and the environment: will it be the enterprise - thus implying a reverse of the burden of proof, ${ }^{206}$ or the state? The former implies that the treaty might offer the mechanisms whereby MNCs should comply in accordance to the spirit of the principle, including the performance of an environ-

mandatory treaty on transnational corporations, banks, other business enterprises, human rights and its historical context. OEIWG, 2015. Available in: <http://www.ohchr.org/Documents/HRBodies/HRCouncil/ WGTransCorp/Session1/TWAProposals_for_Legally_Enforceable_Mandatory_Treaty_on_TNCs_Banks_other_BusinessEnterprisesHumanRights.pdf $>$. p. 2; GLOBAL CAMPAIGN TO DISMANTLE CORPORATE POWER AND STOP IMPUNITY. Eight proposals for the new legally binding international instrument on transnational corporations and buman rghts. OEIWG, 2015. Available in: <http://www.ohchr.org/Documents/HRBodies/HRCouncil/ WGTransCorp/Session1/Global_Campaign_to_Dismantle_Corporate_Power_andStop_Impunity_June-2015_en.pdf >. p. 3; FIAN INTERNATIONAL. Written submission by FIAN international. OEIWG, 2015. Available in: <http://www.ohchr.org/Documents/ HRBodies/HRCouncil/WGTransCorp/Session1/FIAN_International.doc >. p. 8.

204 FITZMAURICE, Malgosia. Contemporary issues in international environmental law. Edward Elgar, 2009. p. 27.

205 UNITED NATIONS. World charter for nature. Environmental Policy and Law, v. 10, n. 2, p. 34-41, 1983. p. 34-41.

206 SCHRÖDER, Meinhard. Precautionary approach/principle. In: WOLFRUM, Rudiger (Ed.). Max Planck encyclopaedia of public international law. United Kingdom: Oxford University Press, 2014. p. 10. mental impact assessment, ${ }^{207}$ as it was suggested during the sessions and in the 'elements of the BHRT' document as a State's obligation to regulate due diligence for parent companies and their supply chains. ${ }^{208}$

This has already been explored not only in the GC, where 'companies are expected to carry out assessments of their environmental impacts and environmental risks' ${ }^{209}$ but also in the Norms, where it is stressed that enterprises should respect the precautionary principle when risk assessments are implemented. ${ }^{210}$

On the contrary, if the states are the ones that should shoulder the onus of proof, then the treaty might define the risks involved in MNCs' operations, and explicitly mention the effective or proportional measures to be taken in order to mitigate them. This specific formulation could inhibit cases like Tătar v. Romania, where despite the fact that the ECtHR did signal the importance of the precautionary principle ${ }^{211}$ as binding European law, ${ }^{212}$ it relied on assorted domestic and international sources. ${ }^{213}$ Therefore, the BHRT may be a possible way to codify and clarify the precautionary principle on this regard.

207 UNITED NATIONS INTERNATIONAL LAW COMMISSION. Yearbook of the international law commission 2000. Geneva: United Nations, v. 2, part. 2, para. 716, 2005. para. 716.

208 UNITED NATIONS HUMAN RIGHTS COUNCIL. Report on the third session of the open-ended intergovernmental working group on transnational corporations and other business enterprises with respect to buman rights. A/HRC/37/67, 2018., para. 26; UNITED NATIONS HUMAN RIGHTS COUNCIL. Report on the first session of the open-ended intergovernmental working group on transnational corporations and other business enterprises with respect to buman rights, with the mandate of elaborating an international legally binding instrument. A/HRC/31/50, 2016.; CHAIRMANSHIP OF THE OEIGWG. Elements for the draft legally binding instrument on transnational corporations and other business enterprises with respect to human rights, 2018. Available in: <https://www.ohchr.org/ Documents/HRBodies/HRCouncil/WGTransCorp/Session3/LegallyBindingInstrumentTNCs_OBEs.pdf $>$.p. 7.

209 MORGERA, Elisa. The UN and corporate environmental responsibility: between international regulation and partnerships. Review of European Community and International Environmental Law, v. 15, n. ,1 p. 93-109, 2006. p. 105.

210 UNITED NATIONS. Commentary on the norms on the responsibilities of transnational corporations and other business enterprises with regard to human rights. UN Doc E/CN4/Sub2/2003/38/Rev2, 2003.

211 EUROPEAN COURT OF HUMAN RIGHTS. Tătar c Roumanie. ECHR App. No. 67021/01, 2009. para. 120.

212 SHELTON, Dinah; BEDERMAN, David. Tătar C. Roumanie. The American Journal of International Law, v. 104, n. 3, p. 247-252, 2010.

213 SHELTON, Dinah; BEDERMAN, David. Tătar C. Roumanie. The American Journal of International Law, v. 104, n. 3, p. 247-252, 2010. 
It is noteworthy that if the precautionary principle is inserted as an open-to-interpretation provision, it might widen the margin of appreciation that an international court could afford in a ruling as a result of a contentious case; precluding the development of a subsidiarity role of the international courts and law-makers, ${ }^{214}$ a useful feature specially in environmental related cases. ${ }^{215}$ Therefore, flexible rules for states, may confer them an ample range of options to justify the breach of an obligation. ${ }^{216}$

The precautionary principle could be designed to be an obligation of conduct, result, or a mix of the two. The first one will provide broad guidelines, as revealed in the context of social, economic and cultural rights; ${ }^{217}$ while the second one will set specific, measurable and objective processes, emulating unambiguous provisions found in some international environmental instruments, like the Protocol of Environmental Protection to the Antarctic Treaty, prohibiting the extraction of minerals. ${ }^{218}$ The third one could be inspired by the Cartagena Protocol on Biosafety to the CBD, which broadly invokes the precautionary principle to justify the rationale of the instrument, ${ }^{219}$ and contemplates a scientifically sound risk assessment whose costs shall be borne by the exporting country; ${ }^{220}$ just like the Draft Articles on Prevention of Transboundary Harm from Hazardous

214 SAUL, Matthew. The european court of human rights' margin of appreciation and the processes of national parliaments. Human Rights Law Review, v. 15, n. 4, p. 745-774, 2015.

215 MÜLLEROVÁ, Hana. Environment playing short-handed: margin of appreciation in environmental jurisprudence of the european court of human rights: environment playing short-handed. Review of European, Comparative \& International Environmental Law, v. 24, n. 1, p. 83-92, 2015.

216 SHANY, Yuval. Toward a general margin of appreciation doctrine in international law? European Journal of International Law, v. 16, n. 5, p. 907-940, 2005.

217 WOLFRUM, Rüdiger. Obligation of result versus obligation of conduct: some thoughts about the implementation of international obligations. In: ARSANJANI, Mahnoush et al. (Ed.). Looking to the Future. Brill, 2010. p. 367.

218 WOLFRUM, Rüdiger. Obligation of result versus obligation of conduct: some thoughts about the implementation of international obligations. In: ARSANJANI, Mahnoush and others (Ed.). Looking to the Future. Brill, 2010. p. 369.

219 SECRETARIAT OF THE CONVENTION ON BIOLOGICAL DIVERSITY (Ed.). Cartagena protocol on biosafety to the convention on biological diversity: text and annexes, 2000. Duty of care around living modified organisms that may pose a risk on biological diversity and human health.

220 SECRETARIAT OF THE CONVENTION ON BIOLOGICAL DIVERSITY (Ed.). Cartagena protocol on biosafety to the convention on biological diversity: text and annexes, 2000.
Activities, where the operator bears the costs of prevention and the state of origin undertakes the necessary expenditure to put in place administrative, financial and monitoring mechanisms. ${ }^{221}$

If a hybrid logic were to be transposed onto the context of the precautionary principle within the BHRT, perhaps requiring a risk assessment of MNCs' operations in host countries could be an obligation of conduct; but at the same time, offsetting its costs onto the home state, an obligation of result. Concomitantly, domestic legislation could oblige locally registered MNCs to fund those risk assessments, placing the obligation of this matter on corporations as an extension of states' obligation of conduct.

Additionally, it may be useful to rely on previous efforts in order to flesh out standards that might not only protect biodiversity, but also the rights of local communities that may be affected by extractive MNCs. For this, the Akwé: Kon Voluntary Guidelines provide suitable insights on environmental and social impact assessments. $^{222}$

Furthermore, other principles related to the environment were also pointed out during discussions; for example, the 'reversal of the burden of proof'223 and the PPP. ${ }^{224}$ However, given the lack of a depth and thorough debate about the implications of those proposals, it is still too precipitous to extrapolate their outcome, although from the businesses perspective, reversing the burden of proof would entail an alteration of due process. ${ }^{225}$ Moreover, it may be inaccurate to define as

\section{UNITED NATIONS INTERNATIONAL LAW COM-} MISSION. Yearbook of the international law commission 2001. New York: United Nations, v. 2, 2007. p. 155.

222 SECRETARIAT OF THE CONVENTION ON BIOLOGICAL DIVERSITY. Akwé Kon: voluntary guidelines for the conduct of cultural, environmental, and social impact assessments regarding developments proposed to take place on, or which are likely to impact on, sacred sites and on lands and waters traditionally occupied or used by indigenous and local communities, 2004. para. 61.

223 CHAIRMANSHIP OF THE OEIGWG. Elements for the draft legally binding instrument on transnational corporations and other business enterprises with respect to buman rights, 2018. Available in: <https://www. ohchr.org/Documents/HRBodies/HRCouncil/WGTransCorp/ Session3/LegallyBindingInstrumentTNCs_OBEs.pdf>. p. 10.

224 UNITED NATIONS HUMAN RIGHTS COUNCIL. Report on the first session of the open-ended intergovernmental working group on transnational corporations and other business enterprises with respect to buman rights, with the mandate of elaborating an international legally binding instrument. A/HRC/31/50, 2016. para. 51.

225 UNITED NATIONS HUMAN RIGHTS COUNCIL. Report on the third session of the open-ended intergovernmental working group on 
a self-standing principle the 'shift of the burden of proof', since it could already be implied depending on the interpretation given to the precautionary principle. As for the PPP, its scope will be discussed further in the section of corporate liability.

To conclude, the environmental principles that were mentioned, even if invoked in an undefined manner, shows the will to accept the conceptual and practical challenges of adapting their scope into the context of a human rights treaty, an area of international law where such principles may be deemed as 'alien'. ${ }^{226}$ However, for forthcoming sessions, it may be relevant to additionally discuss the scope of other principles instilled in treaties such as the UNFCCC, like the principle of 'common but differentiated responsibilities', mostly because it could be helpful to understand that the costs linked to social and environmental risk assessments, either borne by states or MNCs, should consider each country's special circumstances, a measure that could level the playing field for developing countries and their MNCs. ${ }^{227}$

\subsection{Ratione Personae: what enterprises should be included?}

According to HRC Resolution 26/9, the scope of regulation had initially been constrained to MNCs and 'other business enterprises'. The latter is a category explained in a footnote within the same resolution indicating only 'business enterprises that have a transnational character in their operational activities, and does not apply to local businesses registered in terms of relevant domestic law'.228

Firstly, it is still unclear whether a footnote has equivalent normative authority as the core of the resolution, or is just a flexible reference, subject to further inter-

transnational corporations and other business enterprises with respect to buman rights. A/HRC/37/67, 2018. para 52.

226 MORGERA, Elisa. Benefit-sharing as a bridge between the environmental and human rights accountability of multinational corporations. In: BOER, Ben (Ed.). Environmental law dimensions of human rights. United Kingdom: Oxford University Press, 2015. p. 49. 227 NOLLKAEMPER, André. Sovereignty and environmental justice in international law. In: EBBESSON, Jonas; OKOWA, Phoebe (Ed.). Environmental law and justice in context. United Kingdom: Cambridge University Press, 2009. p. 260.

228 UNITED NATIONS HUMAN RIGHTS COUNCIL. Elaboration of an international legally binding instrument on transnational corporations and other business enterprises with respect to buman rights. UN. Doc. A/ HRC/RES/26/9, 2014. para. 1. pretation or modification. ${ }^{229}$ The former compartmentalizes only enterprises with a transnational character, clashing with those who pursued a broader interpretation encompassing all business enterprises - even local companies, ${ }^{230}$ which is underpinned by the UNGP ${ }^{231}$ and echoed by certain states and NGOs alike. ${ }^{232}$ Contrariwise, some states asserted, in a generic fashion, that MNCs should be the only ones to be regulated, claiming that the impacts of human rights are directly linked to the size and structure of MNCs, and that the spirit of the treaty should address the current gap created by undefined MNCs. ${ }^{233}$

One commentator emphasized that legally binding all businesses to comply with all forms of human rights standards would alter the objective of the BHRT. ${ }^{234}$ Whereas regulating only MNCs would imply establishing their definitions either within the treaty or later in domestic legislation. ${ }^{235}$ The formula retrieved in the 'elements for the BHRT' document emphasized that 'a legal definition of MNCs and other businesses is not required, since the determinant factor is the activity undertaken, particularly if such activity has a transnational character'. ${ }^{236}$ Furthermore, it has been indicated in that

229 LOPEZ, Carlos; SHEA, Ben. Negotiating a treaty on business and human rights: a review of the first intergovernmental session. Business and Human Rights Journal, v. 1, n. 1, p. 111-116, 2016. 230 MOHAMADIEH, Kinda; URIBE, Daniel. Business and buman rights: commencing discussions on a legally binding instrument. South Centre Bulletin. Available in: <http://www.southcentre.int/ wp-content/uploads/2015/11/SB87-88_EN.pdf>. p. 12.

231 RUGGIE, John. Guiding principles on business and buman rights: implementing the United Nations "protect, respect and remedy" Framework. A/HRC/17/31, 2011. p. 13.

232 NAMIBIAN DELEGATION. Panel III. OEIGWG, 2015. Available in: <http://www.ohchr.org/Documents/HRBodies/HRCouncil/WGTransCorp/Session1/Panel3/States/Namibia.pdf >.

233 UNITED NATIONS HUMAN RIGHTS COUNCIL. Report on the first session of the open-ended intergovernmental working group on transnational corporations and other business enterprises with respect to buman rights, with the mandate of elaborating an international legally binding instrument. A/HRC/31/50, 2016. para. 58.

234 MOHAMADIEH, Kinda; URIBE, Daniel. Business and buman rights: commencing discussions on a legally binding instrument. South Centre Bulletin. Available in: < http://www.southcentre.int/ wp-content/uploads/2015/11/SB87-88_EN.pdf>. p. 14.

235 MOHAMADIEH, Kinda; URIBE, Daniel. Business and buman rights: commencing discussions on a legally binding instrument. South Centre Bulletin. Available in: <http://www.southcentre.int/ wp-content/uploads/2015/11/SB87-88_EN.pdf>. p. 14.

236 CHAIRMANSHIP OF THE OEIGWG. Elements for the draft legally binding instrument on transnational corporations and other business enterprises with respect to buman rights, 2018. Available in: <https://www. ohchr.org/Documents/HRBodies/HRCouncil/WGTransCorp/ Session3/LegallyBindingInstrumentTNCs_OBEs.pdf $>$. p. 4. 
same document that the instrument should apply to human rights abuses resulting from any business activity with a transnational character, including entities directly or indirectly controlled by them. ${ }^{237}$

The quandary regarding the definition of MNCs in a treaty is redolent of the times when the Norms were drafted, ${ }^{238}$ whose final outcome did envisage a vague definition of $\mathrm{MNCs},{ }^{239}$ including 'all business entities, regardless of their stated corporate form or the international or domestic scope of their business'. ${ }^{240}$ A 'broad and inclusive' formula is also present in the $\mathrm{GC}^{241}$ and the ILO Tripartite Declaration on Multinational Enterprises and Social Policy, ${ }^{242}$ indicating that the OEIGWG has a range of multifaceted and rehashed options to choose from.

Moreover, some NGOs' delegates proposed a 'hybrid option', upon which no type of businesses should be excluded from regulation, while simultaneously drawing provisions addressing specific challenges for MNCs only. ${ }^{243}$ They argued that the footnote in Resolution 26/9 is not entirely clear, assuming that a clear-cut definition of MNCs in the treaty will not only be problematic with respect to overlooking variables that define their 'transnational' character, but also may contribute to the creation of loopholes. ${ }^{244}$ In a similar vein,

237 CHAIRMANSHIP OF THE OEIGWG. Elements for the draft legally binding instrument on transnational corporations and other business enterprises with respect to buman rights. 2018. Available in: <https://www. ohchr.org/Documents/HRBodies/HRCouncil/WGTransCorp/ Session3/LegallyBindingInstrumentTNCs_OBEs.pdf $>$. p. 5 .

238 WEISSBRODT, David; KRUGER, Muria. Norms on the responsibilities of transnational corporations and other business enterprises with regard to human rights current developments. American Journal of International Law, v. 97, n. 4, p. 901-922, 2003.

239 UNITED NATIONS. Norms on the responsibilities of transnational corporations and other business enterprises with regard to buman rights. E/CN4/Sub2/2003/12/Rev2, 2003.

240 WEISSBRODT, David; KRUGER, Muria. Norms on the responsibilities of transnational corporations and other business enterprises with regard to human rights current developments. American Journal of International Law, v. 97, n. 4, p. 901-922, 2003. p. 909.

241 WEISSBRODT, David. Human rights standards concerning transnational corporations and other business entities. Minnesota Journal of International Law, v. 23, n. 2, p. 135-171, 2014. p. 140.

242 INTERNATIONAL LABOUR ORGANIZATION - ILO. Tripartite declaration of principles concerning multinational enterprises and social policy. International Legal Materials, v. 41, n. 1, p. 184-201, 2002. para 6.

243 TREATY ALliAnCE. Panel II: scope. OEIGWG, 2015. Available in: <http://www.ohchr.org/Documents/HRBodies/HRCouncil/WGTransCorp/Session1/Panel2/Others/SOMOJointStatement.pdf $>$. p. 1.

244 TREATy ALLIANCE. Panel II: scope. OEIGWG, 2015. other NGOs decried the 'one-size-fits-all' approach by underscoring the irrelevance of the structure of the enterprise in the milieu of human rights encroachments, recommending the establishment of flexible rules that take into account the size, context and type of business enterprises. ${ }^{245}$

Finally, it might sound tempting, from an environmental protection perspective, to regulate more thoroughly MNCs that profit from the most pollutant activities deployed specially in developing countries. However, the reality is that human rights violations alleged in the context of environmental hazards, have been correlated with all business sectors. ${ }^{246}$ Thus, regulating a segment of MNCs would contradict the universality and non-hierarchical definition of human rights, an aspirational tenet in the treaty. Notwithstanding, if all types of business enterprises were to be included in the treaty, it could be an opportunity to expand environmental protection standards in all supply chains, which may lead to take into consideration climate change related policies or biodiversity protection mechanisms, as already stressed in the OECD Guidelines. ${ }^{247}$

\subsection{Ratione Materiae: what rights should be included?}

The 'subject matter' of the BHRT should bridge the historical chasm between civil and political rights on the one hand, and economic, social and cultural rights on the other, according to a commentator, ${ }^{248}$ while drawing three potential options that should be analy-

Available in: <http://www.ohchr.org/Documents/HRBodies/HRCouncil/WGTransCorp/Session1/Panel2/Others/SOMOJointStatement.pdf>. p. 2.

245 INTERNATIONAL NETWORK FOR ECONOMIC, SOCIAL AND CULTURAL RIGHTS. Joint oral statement on the scope of the legally binding instrument. TNCs and other business enterprises. OEIGWG, 2015. Available in: <http://www.ohchr.org/Documents/HRBodies/HRCouncil/WGTransCorp/Session1/Panel3/ Others/ESCR-NET_Joint_Statement.pdf>.p. 2.

246 MORGERA, Elisa. Benefit-sharing as a bridge between the environmental and human rights accountability of multinational corporations. In: BOER, Bem. (Ed.). Environmental law dimensions of human rights. United Kingdom: Oxford University Press, 2015. p. 41. 247 ORGANISATION FOR ECONOMIC CO-OPERATION AND DEVELOPMENT. OECD guidelines for multinational enterprises, 2011. p. 43

248 DEVA, Surya. Scope of the proposed instrument: what human rights to be covered?. OEIGWG, 2015. Available in: <http://www. ohchr.org/Documents/HRBodies/HRCouncil/WGTransCorp/ Session1/Panel4/Surya_Deva.pdf>.p. 1. 
sed with regards to the breadth of human rights that should be protected: the first one should only address 'gross' human rights abuses; the second should only refer to the 'core' human rights treaties; and the third one is to embrace all human rights instruments while establishing specific provisions with more severe sanctions for 'gross' abuses. ${ }^{249}$

The first option was largely discredited by virtually all stakeholders, while the second was considered too narrow, even if it resonates with the minimum set of rights in Principle 12 of the UNGP. ${ }^{250}$ The third option reconciles with the stance of countries like Bolivia, ${ }^{251}$ Cuba, ${ }^{252}$ Ecuador ${ }^{253}$ and South Africa, ${ }^{254}$ whose views underscore the importance of not omitting environmental rights, the rights of indigenous peoples and even the right to development, invoking the universality of rights enshrined in the Vienna Declaration and Programme of Action. ${ }^{255}$ Nearly all NGOs followed said stance, while adding the right to food and nutrition, ${ }^{256}$

249 DEVA, Surya. Scope of the proposed instrument: what human rights to be covered?. OEIGWG, 2015. Available in: < http://www. ohchr.org/Documents/HRBodies/HRCouncil/WGTransCorp/ Session1/Panel4/Surya_Deva.pdf>. p. 2.

250 RUGGIE, John. Report of the special representative of the secretary general on the issue of buman rights and transnational corporations and other business enterprises. Report submitted before session 17 of the human rights council. A/HRC/17/31, 2011. p. 13.

251 BOLIVIAN DELEGATION. Panel IV: derechos humanos a ser cubiertos bajo el instrumento con respecto a las actividades de las empresas transnacionales y otras empresas. OEIGWG, 2015. Available in: <http://www.ohchr.org/Documents/HRBodies/HRCouncil/WGTransCorp/Session1/Panel4/States/Bolivia_Plurinational_State_of.pdf>.

252 CUBAN DELEGATION. Panel IV: qué violaciones a los derechos humanos deben estar cubiertas bajo el instrumento sobre las empresas transnacionales y otras empresas comerciales?. OEIGWG, 2015. Available in: <http://www.ohchr.org/Documents/ HRBodies/HRCouncil/WGTransCorp/Session1/Panel4/States/ Cuba.pdf $>$. p. 1.

253 ECUADORIAN DELEGATION. Panel IV: qué derechos humanos a ser cubiertos bajo el instrumento sobre las empresas transnacionales y otras empresas de negocios? OEIGWG, 2015 <http://www.ohchr.org/Documents/HRBodies/HRCouncil/ WGTransCorp/Session1/Panel4/States/Ecuador.pdf>. p. 2.

254 SOUTH AFriCAN DELEGATION. Panel IV: human rights to be covered under the instrument with respect to activities of TNCs and other business enterprises? OEIGWG, 2015. Available in: <http://www.ohchr.org/Documents/HRBodies/HRCouncil/ WGTransCorp/Session1/Panel4/States/SouthAfrica.doc>. p. 1.

255 UNITED NATIONS. United Nations world conference on human rights: Vienna declaration and programme of action. International Legal Materials, v. 32, n. 6, p. 1661-1687, 1993.

256 FIAN INTERNATIONAL. Oral statement of FIAN international: panel IV. OEIGWG, 2015. Available in: <http://www.ohchr. org/Documents/HRBodies/HRCouncil/WGTransCorp/Session1/Panel4/Others/FoodFirst_Information_and_Action_Net- the rights of environmental defenders, ${ }^{257}$ the eradication of poverty and a gender-based perspective. ${ }^{258}$

If the afore mentioned stance finds consensus, the obvious question is what will happen to those rights underpinned in international instruments that have no universal recognition, such as regional human rights instruments.

Accordingly, should all types of human rights be included, then both, a self-standing right to a healthy environment as well as procedural and substantive rights related to environmental protection, would automatically be annexed into the BHRT. This includes instruments that protect an autonomous right to a healthy or decent environment, like the recently adopted Escazú Convention on Environmental Rights; ${ }^{259}$ but also the Aarhus Convention, deemed as 'an important extension of environmental rights and of the corpus of human rights law', ${ }^{260}$ which acknowledges the importance of the environment to the enjoyment of basic human rights ${ }^{261}$ and mentions private actors ${ }^{262}$ when contravening national environmental law. ${ }^{263}$ Likewise, the 169 ILO Convention on Indigenous and Tribal Peoples, which protects the FPIC of indigenous peoples in projects that may

workFIAN.pdf $>$. p. 2.

257 FIDH. Panel IV: Scope/Human rights to be covered under the instrument with respect to activities of TNCs and other business enterprises?. OEIGWG, 2015. Available in: <http://www. ohchr.org/Documents/HRBodies/HRCouncil/WGTransCorp/ Session1/Panel4/Others/International_Federation_for_Human_ Rights_Leagues_FIDH.pdf $>$.p. 1.

258 CENTRE FOR APPLIED LEGAL STUDIES. Panel IV: human rights to be included. OEIGWG, 2015. Available in: <http://www.ohchr.org/Documents/HRBodies/HRCouncil/ WGTransCorp/Session1/Panel4/Others/Center_for_Applied_Legal_Studies.pdf $>$.

259 UNITED NATIONS ECONOMIC COMMISSION FOR LATIN AMERICA AND THE CARIBBEAN. Regional agreement on access to information, participation and justice in environmental matters in Latin America and the Caribbean. 2018.

260 BOYLE, Alan. Human rights and the environment: where next?. European Journal of International Law, v. 23, n. 3, p. 613-642, 2012. p. 624.

261 UNITED NATIONS ECONOMIC COMMISSION FOR EUROPE. Convention on access to information, public participation in decision-making and access to justice in environmental matters. International Legal Materials, v. 38, n. 3, p. 517-533, 1999.

262 LAVRYSEN, Luc. The Aarhus Convention: between environmental protection and human rights. In : MARTENS, Paul; MELCHIOR, Michel (Ed.). Liège, Strasbourg, Bruxelles: parcours des droits de l'homme, Anthémis, 2010. p. 655.

263 UNITED NATIONS ECONOMIC COMMISSION FOR EUROPE. Convention on access to information, public participation in decision-making and access to justice in environmental matters. International Legal Materials, v. 38, n. 3, p. 517-533, 1999. p. 524. 
directly affect them, and sets the obligation of carrying out social and environmental impact assessments ${ }^{264}-\mathrm{a}$ legal tool in several cases before regional human rights bodies, ${ }^{265}$ might also be included.

With that said, including rights related to the environment into the BHRT, might be a good opportunity to convey environmental protection in human rights rhetoric, coalescing in a harmonious manner with current IEL. ${ }^{266}$ However, due to a lack of universal state support of said rights in international law - due to technical and political components better resolved in domestic fora, ${ }^{267}$ it will be interesting to witness how these discussions evolve within this drafting process.

\subsection{Responsibility and obligations of corporations: revisiting pillar two of the UNGP}

Pillar two of the UNGP and its role in the BHRT's drafting process was pivotal in this discussion. According to some delegates, 'responsibility', in the context of corporations, should be differentiated from connotations found in the UNGP on the one hand, and in CSR contexts on the other. ${ }^{268}$

Cuba proposed that companies shall disclose all the information regarding preventive plans of human rights protection and other due diligence procedures. ${ }^{269}$ The Ecuadorian delegation stressed that direct obligations for corporations can be found already in several instru-

264 INTERNATIONAL LABOUR ORGANIZATION - ILO. Convention concerning indigenous and tribal peoples in independent countries. International Legal Materials, v. 28, n. 6, p. 1382-1392, 1986.

265 COURTIS, Christian. Notes on the implementation by latin american courts of the ILO convention 169 on indigenous peoples. International Journal on Minority and Group Rights, v. 18, n. 4, p. 433-460, 2011.

266 BOYLE, Alan. Human rights and the environment: where next?. European Journal of International Law, v. 23, n. 3, p. 613-642, 2012. p. 633.

267 HANDL, Günter. Human rights and the protection of the environment. In: EIDE, Asbjørn; KRAUSE, Catarina; ROSAS, Allan (Ed.). Economic, social \& cultural rights: a textbook. 2. ed. M Nijhoff Publishers, 2001. p. 305.

268 MOHAMADIEH, Kinda; URIBE, Daniel. Business and buman rights: commencing discussions on a legally binding instrument. South Centre Bulletin. Available in: <http://www.southcentre.int/ wp-content/uploads/2015/11/SB87-88_EN.pdf>. p. 25.

269 CUBAN DELEGATION. Panel VI: aumentando la responsabilidad de las empresas transnacionales y otras empresas. OEIGWG, 2015. Available in: <http://www.ohchr.org/Documents/ HRBodies/HRCouncil/WGTransCorp/Session1/Panel6/States/ Cuba.pdf>. p. 2. ments of international law, namely the Convention on Civil Liability for Oil Pollution Damage, which might inspire the design of direct obligations upon companies in the treaty. ${ }^{270}$ The South African delegation deemed that the UNGP should set the ground for liability and accountability for corporations in international human rights. ${ }^{271}$

NGOs proposed the collective responsibility of MNCs with respect to their subsidiaries. ${ }^{272}$ Moreover, it was advised that states should pass national legislation aiming to define obligations for MNCs to abstain from any activity that could cause ecological harm; to conduct independent ex ante and ex post human rights and environmental impact assessments; to put in place access to information mechanisms for individuals and communities potentially affected by MNCs' operations; to implement on-going human rights and environmental monitoring systems; and to comply with judiciary and administrative decisions. ${ }^{273}$

According to some participants, the standard whereby business enterprises would certainly be bound to, is human rights due diligence, which would include several elements - like FPIC of indigenous peoples, ${ }^{274}$ and whose definition and implementation should be left to states looking to regulate companies operating at home or abroad, while taking due consideration of their supply chains. ${ }^{275}$

270 ECUADORIAN DELEGATION. Panel IV: qué derechos humanos a ser cubiertos bajo el instrumento sobre las empresas transnacionales y otras empresas de negocios? OEIGWG, 2015 <http://www.ohchr.org/Documents/HRBodies/HRCouncil/ WGTransCorp/Session1/Panel4/States/Ecuador.pdf>. p. 2.

271 SOUTH AFRICAN DELEGATION. Panel VI: enhancing the responsibility of transnational corporations and other business enterprises to respect human rights, including prevention, mitigation and remediation. OEIGWG, 2015. Available in: < http://www. ohchr.org/Documents/HRBodies/HRCouncil/WGTransCorp/ Session1/Panel6/States/South_Africa.pdf>. p. 2.

272 CETIM. Panel VI. OEIGWG, 2015. Available in: <http://www.ohchr.org/Documents/HRBodies/HRCouncil/ WGTransCorp/Session1/Panel6/Others/CETIM.pdf>.

273 FIAN INTERNATIONAL. Oral statement of FIAN international: panel VI. OEIGWG, 2015. Available in: <http://www.ohchr. org/Documents/HRBodies/HRCouncil/WGTransCorp/Session1/Panel6/Others/FoodFirst_Information_and_Action_Network_FIAN.pdf $>$.p. 1.

274 UNITED NATIONS HUMAN RIGHTS COUNCIL. Report on the first session of the open-ended intergovernmental working group on transnational corporations and other business enterprises with respect to buman rights, with the mandate of elaborating an international legally binding instrument. A/HRC/31/50, 2016. para. 86.

275 FIDH. Panel VT: enhancing the responsibility of TNCs and other business enterprises to respect human rights, including pre- 
In the document of the 'elements for a BHRT', it was stated that MNCs shall have both positive and negative obligations. The former is related to creating, implementing and monitoring internal policies aligned with internationally recognized human rights standards; while the latter is connected to refraining from activities that would undermine the rule of law. ${ }^{276}$

In this vein, it was suggested to ponder the relevance of the UNFCCC, the Vienna Convention for the Protection of the Ozone Layer and its Montreal Protocol on Substances that Deplete the Ozone Layer, as instruments that set out compliance mechanisms and annexes subject of modification at the meeting of the parties to ensure precision and flexibility as a strategy for enhancing compliance and establish due diligence gauges. ${ }^{277}$

It is worth clarifying that during the discussions, stakeholders were mostly using the definition of 'responsibility' as an obligation rather than as a breach thereto. ${ }^{278}$ With this in mind, two conflicting postures arose: direct obligations for MNCs on the one hand, and indirect obligations through states on the other. However, in-depth debate about the implications of either of those positions was notoriously absent.

The 'direct-obligation' approach is based on the need that corporations - as power-holders, shall also protect human rights, thus striking a balance under international law between the rights of corporations enshrined in BITs, and human rights embedded in the BHRT, provided that both are anchored in international agreements, thus granting them equal value. ${ }^{279}$ Its main shortcoming, however, is that it overlooks fundamental distinctions

vention, mitigation and remediation. OEIGWG, 2015. Available in: <http://www.ohchr.org/Documents/HRBodies/HRCouncil/ WGTransCorp/Session1/Panel6/Others/International_Federation_for_Human_Rights_Leagues_FIDH.pdf >.p. 1.

276 CHAIRMANSHIP OF THE OEIGWG. Elements for the draft legally binding instrument on transnational corporations and other business enterprises with respect to human rights, 2018. Available in: <https://www. ohchr.org/Documents/HRBodies/HRCouncil/WGTransCorp/ Session3/LegallyBindingInstrumentTNCs_OBEs.pdf>. p. 6.

277 UNITED NATIONS HUMAN RIGHTS COUNCIL. Report on the third session of the open-ended intergovernmental working group on transnational corporations and other business enterprises with respect to buman rights. A/HRC/37/67, 2018. paras. 97, 98.

278 NOLLKAEMPER, André. Responsibility of transnational corporations in international environmental law: three perspectives. In: WINTER, Gerd (Ed.). Multilevel governance of global environmental change. United Kingdom: Cambridge University Press, 2006. p. 182. 279 BILCHITZ, David. The necessity for a business and human rights treaty. Business and Human Rights Journal, v. 1, n. 2, p. 203-227, 2016. p. 216. between the private and the public realms, misconceiving or overlapping each dimensions' essential roles, ${ }^{280}$ and giving free rein to private entities to 'capture' an international regime designed to protect individuals, as was underscored by some NGOs. ${ }^{281}$

Furthermore, it is still unclear how exactly those 'direct obligations' will be executed, or how they are going to abate the inconsistency that stems from the imposition of obligations for 'private subjects of international law' who will likely refrain to be bound by a norm that opposes their interests. The options to deal with this is that either MNCs become also part of the treaty or - as in the international humanitarian law regime with respect to rebel groups - they are bound by default to the treaty. ${ }^{282}$

Contrariwise, the 'indirect obligations' approach is already an existent paradigm, where states are the means for MNCs' compliance of human rights obligations, therefore, adding an environmental dimension therein should be less complex. Then again, since it entrusts human rights protection exclusively upon the state, it falls short in recognizing a universal duty of protection. ${ }^{283}$

A good example of the 'direct obligation' approach is Section 1502 of the Dodd-Frank Act, a US domestic law that seeks to raise investors and consumers' awareness through transparency 'on potential corporate complicity in human rights abuses, primarily in the Democratic Republic of the Congo'. ${ }^{284}$ Domestic and foreign companies, as a form of due diligence, must report the origin of certain minerals in their products in order to

280 BILCHITZ, David. Corporations and the limits of statebased models for protecting fundamental rights in international law. Indiana Journal of Global Legal Studies, v. 23, n. 1, p. 143-170, 2016. 281 FIAN INTERNATIONAL. Written submission by FIAN international. OEIWG, 2015. Available in: <http://www.ohchr.org/ Documents/HRBodies/HRCouncil/WGTransCorp/Session1/ FIAN_International.doc $>$.p. 9-10.

282 NOLLKAEMPER, André. Responsibility of transnational corporations in international environmental law: three perspectives. In: WINTER, Gerd (Ed.). Multilevel governance of global environmental change. United Kingdom: Cambridge University Press, 2006. p. 195. 283 BILCHITZ, David. Corporations and the limits of statebased models for protecting fundamental rights in international law. Indiana Journal of Global Legal Studies, v. 23, n. 1, p. 143-170, 2016. p. 166.

284 NARINE, Marcia. From Kansas to the Congo: why naming and shaming corporations through the Dodd-Frank act's corporate governance disclosure won't solve a human rights crisis emerging issues in social enterprise. Regent University Law Review, v. 25, p. 351401, 2012. 
avoid the funding of local groups linked to human rights violations.

Although the cited example is confined to national jurisdiction and does not incorporate a direct environmental component, it nonetheless evinces the positive impact behind drawing obligations for companies as a mandatory due diligence requirement to operate. In that vein, states under the treaty could flesh out due diligence obligations that not only touches upon human rights, but also environmental protection.

Principle 17 of the UNGP contemplates corporate due diligence as a way to identify, prevent, mitigate and account for adverse human rights impacts, including current and potential ones. ${ }^{285}$ In that regard, the Norms, ${ }^{286}$ as a way to materialize the concept of due diligence, enshrined the need to carry out social and environmental assessments before and during the life cycle of the operation, ensuring 'that the burden of the negative environmental consequences does not fall on vulnerable racial, ethnic and socioeconomic groups'. ${ }^{287}$ Therefore, corporate due diligence could be delineated taking into account existent standards of environmental and social impact assessments intertwined with nascent standards on human rights impact assessments. ${ }^{288}$

Regardless of the approach taken by the OEIWG with respect to direct or indirect obligations for MNCs, fixing binding standards of corporate due diligence is arguably a step forward towards filling international law lacuna; additionally, it is a good opportunity to merge standards from two different law regimes, a challenge that may find insights in current national and international law, as was demonstrated. Said examples could also be transposed onto state-run companies, a category barely mentioned during the discussions and whose grey areas could ignite further contention, even if Principle 4 of the UNGP takes due notice of their importance. ${ }^{289}$

285 RUGGIE, John. Guiding principles on business and human rights: implementing the United Nations "protect, respect and remedy" Framework. A/HRC/17/31, 2011. p. 16.

286 WEISSBRODT, David. Human rights standards concerning transnational corporations and other business entities. Minnesota Journal of International Law, v. 23, n. 2, p. 135-171, 2014. p. 153.

287 MORGERA, Elisa. Corporate accountability in international environmental law. United Kingdom: Oxford University Press, 2009. p. 180.

288 MASSARANI, Tarek; TATGENHORST DRAKOS, Margo; PAJKOWSKA, Joanna. Extracting corporate responsibility: towards a human rights impact assessment. Cornell International Law Journal, v. 40, n. 1, p. 135-169, 2007.

289 RUGGIE, John. Guiding principles on business and buman rights:

\subsection{Liability for businesses}

Delegates highlighted that the treaty should address frequent litigation obstacles to render MNCs accountable, like complex corporate structures or the doctrine of forum non conveniens. ${ }^{290}$ Moreover, it was claimed that standards should adapt to different civil and criminal liability contexts or diverse legal systems and traditions, while also allowing inter-state cooperation for legal enforcement and liability for all stages in the supply chain. In addition, the level of liability could be proportional to the level of due diligence measures taken from a parent company vis-à-vis its subsidiaries, implying that rules should be adjusted on a case-by-case basis. ${ }^{291}$

Conversely, a delegate from an employers' organization proposed that instead of focusing on standards, the treaty should have an approach where specific conducts should be penalized and a pragmatic victim-oriented approach should be embraced. ${ }^{292}$ Moreover, defining the jurisdiction where the harmful conduct took place and sanctioning them based on the level of damage inflicted should be the focus. ${ }^{293}$

Bolivia and Cuba stressed that impairments of human rights perpetrated by parent companies and/or their subsidiaries should amount to the executives' liability. ${ }^{294}$ To this, Venezuela proposed a list of harmful conducts and their corresponding sanctions therein. ${ }^{295}$

implementing the United Nations "protect, respect and remedy" Framework. A/HRC/17/31, 2011. p. 9.

290 DEVA, Surya. Legal liability of TNCs and other business enterprises: what standards and for which conducts?. OEIGWG, 2015. Available in: <http://www.ohchr.org/Documents/HRBodies/HRCouncil/WGTransCorp/Session1/Panel7/Surya_DevaVII.pdf $>$. p. 1.

291 DEVA, Surya. Legal liability of TNCs and other business enterprises: what standards and for which conducts?. OEIGWG, 2015. Available in: <http://www.ohchr.org/Documents/HRBodies/HRCouncil/WGTransCorp/Session1/Panel7/Surya_DevaVII.pdf > . p. 2.

292 SUAREZ, Roberto. Legal liability of transnational corporation. OEIGWG, 2015. Available in: <http://www.ohchr.org/Documents/HRBodies/HRCouncil/WGTransCorp/Session1/Panel7/ Roberto_Suarez.pdf>.p. 3.

293 MOHAMADIEH, Kinda; URIBE, Daniel. Business and buman rights: commencing discussions on a legally binding instrument. South Centre Bulletin. Available in: < http://www.southcentre.int/ wp-content/uploads/2015/11/SB87-88_EN.pdf>.p. 31.

294 BOLIVIAN DELEGATION. Panel VII: responsabilidad legal de las empresas transnacionales. OEIGWG, 2015. Available in: <http://www.ohchr.org/Documents/HRBodies/HRCouncil/ WGTransCorp/Session1/Panel7/States/Bolivia_Plurinational_ State_ofVII.pdf $>$.

295 MOHAMADIEH, Kinda; URIBE, Daniel. Business and hu- 
Ecuador recommended setting a nationality test in order to lift the corporate veil, which may include, inter alia, the country where the company is domiciled, the jurisdiction where its operations take place or the nationality of their shareholders. ${ }^{296}$

An NGO cited the Australian criminal code regarding 'fault elements other than negligence', whereby it is stated, inter alia, that either the body corporate's board of directors or a high managerial agent could be held liable if expressly, tacitly or impliedly authorised or permitted the commission of an offence. ${ }^{297}$ Furthermore, shared liability of MNCs for the 'activities of their subsidiaries, suppliers, licensees and subcontractors', was also stressed. ${ }^{298}$

Moreover, the need of drawing legal liability provisions to shift the burden of proof from the claimant to the defendant was proposed by an NGO, since 'those affected by corporate injustice, the complex organisational processes within a company and its business relationships are extremely difficult to determine and prove'. ${ }^{299}$

All this begs the question of whether due diligence could be considered a measure that attenuates or exempts liability of MNCs and their subsidiaries, or not. The outcome of this question will depend on whether the PPP, if included in the treaty, will be extensive to the parent company and its subsidiaries or restrictive to each supplier in the value chain. In this sense, international liability regimes are mostly designed around the

man rights: commencing discussions on a legally binding instrument. South Centre Bulletin. Available in: < http://www.southcentre.int/ wp-content/uploads/2015/11/SB87-88_EN.pdf>. p. 33.

296 ECUADORIAN DELEGATION. Panel VII: responsabilidad legal de las empresas transnacionales y de otras empresas: qué estándares para la responsabilidad legal corporativa y para qué tipo de conducta? OEIGWG, 2015. Available in: <http://www.ohchr. org/Documents/HRBodies/HRCouncil/WGTransCorp/Session1/Panel7/States/Ecuador.pdf $>$.

297 ESCR-NET. Intervention from the floor during panel VII. OEIGWG, 2015. Available in: <http://www.ohchr.org/Documents/ HRBodies/HRCouncil/WGTransCorp/Session1/Panel7/Others/ ESCRNet.pdf>.

298 FRIENDS OF THE EARTH INTERNATIONAL. Oral statement FoEI at panel VII on legal liability of TNCs and other business enterprises. OEIGWG, 2015. Available in: <http://www.ohchr.org/ Documents/HRBodies/HRCouncil/WGTransCorp/Session1/ Panel7/Others/Friends_of_the_Earth_International.pdf $>$.

299 CIDSE. Panel VII: content: standards for legal accountability TNCs and what conduct?. OEIGWG, 2015. Available in: <http://www.ohchr.org/Documents/HRBodies/HRCouncil/ WGTransCorp/Session1/Panel7/Others/CIDSE_Joint_Statement.pdf $>$. concept of strict limited liability for private operators in specific high risk activities, ${ }^{300}$ like the movement of ultra-hazardous substances, where private due diligence is unknown, and paradoxically an integral implementation of the PPP is yet to be consolidated. ${ }^{301}$

If the BHRT includes the PPP, there should be a balance between the strict liability standard and the implications of implementing MNCs due diligence, which may be used as a potential defence argument should they commit wrongful acts. It is noteworthy that the SRSG indicated that human rights due diligence, by itself, should not absolve a company from liability; ${ }^{302}$ a caveat that resonates with the formula in the Convention on Civil Liability for Damage Resulting from Activities Dangerous to the Environment, whereby an operator is exempted from liability, inter alia, if the act was caused by a third party intending to cause damage, and having implemented safety measures first. ${ }^{303}$

Perhaps the first step to implement the PPP under this new treaty is to identify the polluter or the human rights transgressor, to whom a nationality test could be applied, and depending on the size of the company, determine whether home states should assume part of the burden as 'residual sources of redress'. ${ }^{304}$ This could be seen as a progressive implementation of principles 13 and 16 of the Rio Declaration, with respect to liability and compensation for adverse effects of environmental damage, and the internalization of environmental costs. $^{305}$

300 LUPPI, Barbara; PARISI, Francesco; RAJAGOPALAN, Shruti. The rise and fall of the polluter-pays principle in developing countries. International Review of Law and Economics, v. 32, n. 1, p. 135-144, 2012.

301 MORGERA, Elisa. Corporate accountability in international environmental law. United Kingdom: Oxford University Press, 2009. p. 40-41; BIRNIE, Patricia; BOYLE, Alan; REDGWELL, Catherine. International law and the environment. 3. ed. United Kingdom: Oxford University Press, 2009. p. 325.

302 RUGGIE, John. Business and human rights: further steps toward the operationalization of the "protect, respect and remedy" framework: report of the special representative of the secretary general on the issue of human rights and transnational corporations and other business enterprises. UN Doc. A/HRC/14/27, 2010. para. 86. 303 COUNCIL OF EUROPE. Convention on civil liability for damage resulting from activities dangerous to the environment. International Legal Materials, v. 32, n. 5, p. 1228-1246, 1993. p. 1234.

304 BOYLE, Alan. Globalising environmental liability: the interplay of national and international law. Journal of Environmental Law, v. 17, n. 1, p. 3-26, 2005. p. 8.

305 UNITED NATIONS. Conventions and agreements international developments. Commonwealth Law Bulletin, v. 19, n. 1, p. $247-$ 316, 1993. 


\section{Conclusions}

It is clear that since 2006, the prolific role of the HRC in bolstering the human rights regime is undeniable, ${ }^{306}$ a contribution that certainly extends to the current endeavour of crafting a BHRT, which indubitably is a new opportunity to keep developing a vital service for humanity. In that sense, a new BHRT is feasible, although it entails colossal challenges that will have to be dealt with caution, without repeating mistakes from the past; ${ }^{307}$ and a way to do it, is by understanding that law making processes are frequently diplomatic facades, veiling each country's political agendas. ${ }^{308}$ That is why, the drafters of the BHRT should consider the risks of paucity of precision when assigning direct duties to MNCs and other businesses; namely a potential distortion of the human rights regime by consigning states' obligations to non-state actors ${ }^{309}$. This risk may increase taking into consideration that the main proponents and supporters of the treaty are countries not particularly deemed as democratic, ${ }^{310}$ demonstrating the importance of legislative rigour and a vibrant diversity of voices in the HRC.

To illustrate the previous point, almost every stakeholder that was present in all three sessions had similar views on nearly all the basic structure of the BHRT, except for the contended point regarding the scope of regulation. States were keen on regulating only MNCs, while NGOs and experts suggested to extend it to all types of businesses. Fortunately, an understanding was reached as to regulate all businesses entities with a transnational character, avoiding a potential collapse that might stalled subsequent negotiations. This goes without mentioning the absence of key actors, like the US, which without them, thwarting the adoption of a final outcome is a foreseeable scenario, analogous to the unsuccessful experience of the UNCCTC and the Norms.

306 RAMCHARAN, Bertrand. The law, policy and politics of the UN. Brill Nijhoff, 2015. p. 164.

307 RUGGIE, John. A UN business and buman rights treaty?. Available in: <https://www.hks.harvard.edu/m-rcbg/CSRI/UNBusinessandHumanRights'Treaty.pdf $>$. p. 3.

308 BOYLE, Alan; CHINKIN, Christine. The making of international law. United Kingdom: Oxford University Press, 2007. p. 103.

309 KNOX, John. Horizontal human rights law. The American Journal of International Law, v. 102, n. 1, p. 1-47, 2008. p. 1-47.

310 CAMPBELL, David et al. Key findings of the democracy ranking 2015. Available in: <http://democracyranking.org/ranking/2015/ data/Scores_of_the_Democracy_Ranking_2015_A4.pdf >.p. 3.
Evidently, it is difficult to assess, at least at this early stage of drafting, what the substantive content, operative procedures, or practical shortcomings the BHRT will entail, specially for environmental considerations; however, the chances for environmental protection are multiple if drafters start discussing them in subsequent drafting stages. What may spark further debate on environmental dimensions are the broad assertions regarding environmental principles that stakeholders made during the first three sessions. But again, vaguely worded declarations might be interpreted as an attempt to internationalize domestic standards, an ambitious endeavour that should be meticulously examined.

Notwithstanding, it is worth of notice that several IEL instrument were mentioned during the sessions; signalling an attempt of cross-fertilization between distinct areas of law during these stages of the drafting, and to that end, there is a multiple array of IEL tools that could be useful in the future. Needles to say, the HRC is a human rights body, not a conference of the parties of an environmental agreement; and from what was perceived at this early stage, the chasm that divides both regimes, has not yet been bridged.

Ostensibly, the UNGP and other voluntary initiatives designed to provide guidance on corporate human rights responsibility, will keep developing and be progressively inserted onto global law and policy, concomitantly with the negotiations of the BHRT, however, if an honest and useful addition of environmental dimensions within these initiatives are intended to be included, it is 'still necessary to identify the relationship between human rights obligations and environmental protection in order to determine what environmental responsibilities we expect corporations to respect'. ${ }^{311}$

Considering that this document has mainly addressed the question of corporations' responsibility to respect human rights and the environment - or the second pillar in UNGP's vernacular, the plethora of ramifications around these discussions are still ill-explored; and it hints the need to keep examining the way in which the rest of the pillars interweave with other phenomena that might be slightly out of the scope of the HRC. That path must be followed in order to clinch this heated and elongated debate. Of course, the focus of this

311 BOYLE, Alan. Human rights and the environment: where next?. European Journal of International Law, v. 23, n. 3, p. 613-642, 2012. p. 621. 
unresolved matter should always be the global victims, and in that category, it might be wise to make room for the environment.

\section{References}

AFFOLDER, Natasha. Square pegs and round holes?. In: BOER, Ben (Ed.). Environmental law dimensions of human rights. United Kingdom: Oxford University Press, 2015.

ALVAREZ, Jose. Are corporations "subjects" of international law? Santa Clara Journal of International Law, v. 9, n. 1, 2011.

ANAYA, James. Statement by Professor James Anaya special Rrapporteur on the rights of indigenous peoples. FORUM ON BUSINESS AND HUMAN RIGHTS, 2012. Available in: <http://unsr.jamesanaya.org/statements/forumon-business-and-human-rights-2012-statement-by-professor-james-anaya $>$.

ASSOCIATION OF SOUTHEAST ASIAN NATIONS. ASEAN Human Rights Declaration, 2012.

AUSTRALIA. Supreme Court of Victoria at Melbourne. Gagarimabu v Broken Hill proprietary co Ltd, VSC 517, 2001.

BAUMANN-PAULY, Dorothée; POSNER, Michael. Making the business case for human rights: an assessment. In: BAUMANN-PAULY, Dorothée; NOLAN, Justine (Ed.). Business and human rights: from principles to practice, Routledge, 2016.

BILCHITZ, David. Corporations and the limits of state-based models for protecting fundamental rights in international law. Indiana Journal of Global Legal Studies, v. 23, n. 1, p. 143-170, 2016.

BILCHITZ, David. The necessity for a business and human rights treaty. Business and Human Rights Journal, v. 1, n. 2, p. 203-227, 2016.

BIRNIE, Patricia; BOYLE, Alan; REDGWELL, Catherine. International law and the environment. 3. ed. United Kingdom: Oxford University Press, 2009.

BLITT, Robert. Beyond Ruggie's guiding principles on business and human rights: charting an embracive approach to corporate human rights compliance. Texas International Law Journal, v. 48, n. 1, p. 33-62, 2012.
BOLIVIAN DELEGATION. Panel I: principios, conceptos y elementos, 2015. Available in: <http:// www.ohchr.org/Documents/HRBodies/HRCouncil/ WGTransCorp/Session1/Panel1/States/BOLIVIA_ PLURINATIOANL_STATE_OF.pdf $>$.

BOLIVIAN DELEGATION. Panel IV: derechos humanos a ser cubiertos bajo el instrumento con respecto a las actividades de las empresas transnacionales y otras empresas. OEIGWG, 2015. Available in: <http:/ / www.ohchr.org/Documents/HRBodies/HRCouncil/ WGTransCorp/Session1/Panel4/States/Bolivia_Plurinational_State_of.pdf $>$.

BOLIVIAN DELEGATION. Panel VII: responsabilidad legal de las empresas transnacionales. OEIGWG, 2015. Available in: <http://www.ohchr.org/Documents/HRBodies/HRCouncil/WGTransCorp/Session1/Panel7/States/Bolivia_Plurinational_State_ ofVII.pdf $>$.

BOYD, David. Constitutional right to a healthy environment, the feature: environmental causes and the Law. Law Now, v. 37, n. 4, p. 9-13, 2012.

BOYLE, Alan. Globalising environmental liability: the interplay of national and international law. Journal of Environmental Law, v. 17, n. 1, p. 3-26, 2005.

BOYLE, Alan; CHINKIN, Christine. The making of international law. United Kingdom: Oxford University Press, 2007.

BOYLE, Alan. Human rights and the environment: where next?. European Journal of International Law, v. 23, n. 3, p. 613-642, 2012.

BUHMANN, Karin. The development of the "UN framework": a pragmatic process towards a pragmatic output. In: MARES, Radu (Ed.). The UN guiding principles on business and buman rights: foundations and implementation. Martinus Nijhoff, 2012.

CAMPBELL, David et al. Key findings of the democracy ranking 2015. Available in: <http://democracyranking. org/ranking/2015/data/Scores_of_the_Democracy_ Ranking_2015_A4.pdf>.

CANADA. British Columbia Supreme Court. Garcia v Tahoe resources inc. BCSC 2045, 2015.

CANADA. Québec Canadian Court of Appeal. Bil'in village councilv Park. QCCA 2470, 2008.

CARASCO, Emily; SINGH, Jang. Towards holding 
transnational corporations responsible for human rights. European Business Review, v. 22, n. 4, p. 432-445, 2010 .

CENTRE FOR APPLIED LEGAL STUDIES. Panel IV: human rights to be included. OEIGWG, 2015. Available in: <http://www.ohchr.org/Documents/ HRBodies/HRCouncil/WGTransCorp/Session1/ Panel4/Others/Center_for_Applied_Legal_Studies. $\mathrm{pdf}>$.

CENTER FOR CONSTITUTIONAL RIGHTS. Wiwa et al. v. royal dutch petroleum et al. Available in: <https:// ccrjustice.org/node/1505>.

CETIM. Panel VI. OEIGWG, 2015. Available in: <http://www.ohchr.org/Documents/HRBodies/HRCouncil/WGTransCorp/Session1/Panel6/Others / CETIM.pdf $>$.

CHAIRMANSHIP OF THE OEIGWG. Elements for the draft legally binding instrument on transnational corporations and other business enterprises with respect to human rights, 2018. Available in: <https://www.ohchr.org/Documents/ HRBodies/HRCouncil/WGTransCorp/Session3/LegallyBindingInstrumentTNCs_OBEs.pdf $>$.

CHEN, Victor; JOHNSON, Lise. Emerging market MNEs and social responsibility: an institutional pressure perspective. Transnational Corporations, v. 22, n. 3, p. 1-4, 2013.

CIDSE. Panel VII: content: standards for legal accountability TNCs and what conduct?. OEIGWG, 2015. Available in: <http://www.ohchr.org/Documents/HRBodies/HRCouncil/WGTransCorp/Session1/Panel7/ Others/CIDSE_Joint_Statement.pdf $>$.

CLAPHAM, Andrew. Human rights obligations of non-state actors. United Kingdom: Oxford University Press, 2006.

COCKBURN, Iain; SLAUGHTER, Matthew. The global location of biopharmaceutical knowledge activity: new findings, new questions. Innovation Policy and the Economy, v. 10, p. 129-157, 2010.

COTULA, Lorenzo. Property in a shrinking planet: fault lines in international human rights and investment law. International Journal of Law in Context, v. 11, n. 2, p. 113-134, 2015.

COUNCIL OF EUROPE. Convention on civil liability for damage resulting from activities dangerous to the environment. International Legal Materials, v. 32, n. 5, p. 1228-1246, 1993.
COURTIS, Christian. Notes on the implementation by latin american courts of the ILO convention 169 on indigenous peoples. International Journal on Minority and Group Rights, v. 18, n. 4, p. 433-460, 2011.

CUBAN DELEGATION. Panel I: principios para un instrumento jurídicamente vinculante sobre corporación transnacionales y otros empresas en relación con los derechos humanos, 2015. Available in: <http:// www.ohchr.org/Documents/HRBodies/HRCouncil/ WGTransCorp/Session1/Panel1/States/CUBA.pdf>.

CUBAN DELEGATION. Panel IV: qué violaciones a los derechos humanos deben estar cubiertas bajo el instrumento sobre las empresas transnacionales y otras empresas comerciales?. OEIGWG, 2015. Available in: <http://www.ohchr.org/Documents/HRBodies/ HRCouncil/WGTransCorp/Session1/Panel4/States/ Cuba.pdf $>$.

CUBAN DELEGATION. Panel VT: aumentando la responsabilidad de las empresas transnacionales y otras empresas. OEIGWG, 2015. Available in: <http:// www.ohchr.org/Documents/HRBodies/HRCouncil/ WGTransCorp/Session1/Panel6/States/Cuba.pdf $>$.

CUBAN DELEGATION, Panel VII: responsabilidad legal de las empresas transnacionales y otras empresas con respecto a los derechos humanos. OEIGWH, 2015. Available in: <http://www.ohchr.org/Documents/ HRBodies/HRCouncil/WGTransCorp/Session1/Panel7/States/Cuba.pdf $>$.

DEVA, Surya. Legal liability of TNCs and other business enterprises: what standards and for which conducts?. OEIGWG, 2015. Available in: <http://www.ohchr. org/Documents/HRBodies / HRCouncil/WGTransCorp/Session1/Panel7/Surya_DevaVII.pdf>.

DEVA, Surya. Scope of the proposed instrument: what human rights to be covered?. OEIGWG, 2015. Available in: <http://www.ohchr.org/Documents/HRBodies / HRCouncil/WGTransCorp/Session1/Panel4/Surya_ Deva.pdf $>$.

DONALD, Kate. Human rights practice: a means to environmental ends? Oñati Journal of Emergent Socio-Legal Studies, v. 3, n. 5, p. 908-930, 2013.

DUPUY, Pierre-Marie. International environmental law: looking at the past to shape the future. In: DUPUY, Pierre-Marie; VIÑUALES, Jorge (Ed.). Harnessing foreign investment to promote environmental protection: incentives and 
safeguards. United Kingdom: Cambridge University Press, 2013.

ECUADORIAN DELEGATION. Panel II: ámbito de aplicación de un instrumento prospectivo: alcance del instrumento; empresas transnacionales y otras empresas comerciales, conceptos y naturaleza jurídica en el derecho internacional, 2015. Available in: <http:// www.ohchr.org/Documents/HRBodies/HRCouncil/ WGTransCorp/Session1/Panel2/States/ECUADORStatement-OEIWG-PanelII.pdf>.

ECUADORIAN DELEGATION. Panel IV: qué derechos humanos a ser cubiertos bajo el instrumento sobre las empresas transnacionales y otras empresas de negocios? OEIGWG, 2015 <http://www.ohchr.org/ Documents/HRBodies/HRCouncil/WGTransCorp/ Session1/Panel4/States/Ecuador.pdf>.

ECUADORIAN DELEGATION. Panel VI: mejorando la responsabilidad de las empresas transnacionales y otras empresas de negocios con respecto a los derechos humanos, incluyendo prevención, mitigación y remediación. OEIGWG, 2015. Available in: <http:// www.ohchr.org/Documents/HRBodies/HRCouncil/ WGTransCorp/Session1/Panel6/States/Ecuador. pdf $>$.

ECUADORIAN DELEGATION. Panel VII: responsabilidad legal de las empresas transnacionales y de otras empresas: qué estándares para la responsabilidad legal corporativa y para qué tipo de conducta? OEIGWG, 2015. Available in: <http://www.ohchr.org/Documents/HRBodies/HRCouncil/WGTransCorp/Session1/Panel7/States/Ecuador.pdf $>$.

ESCR-NET. Intervention from the floor during panel VII. OEIGWG, 2015. Available in: <http://www.ohchr. org/Documents/HRBodies/HRCouncil/WGTransCorp/Session1/Panel7/Others/ESCRNet.pdf>.

EUROPEAN COURT OF HUMAN RIGHTS. Fadeyeva $v$ Russian Federation: judgment, merits and just satisfaction. ECHR App No 55723/00, 2005.

EUROPEAN COURT OF HUMAN RIGHTS. Guerra and others. $v$ Italy: judgment, merits and just satisfaction. ECHR App No 14967/89, 1998.

EUROPEAN COURT OF HUMAN RIGHTS. López Ostra v Spain: merits and just satisfaction. ECHR App no 16798/90, 1994.

EUROPEAN COURT OF HUMAN RIGHTS. Tătar c
Roumanie. ECHR App. No. 67021/01, 2009.

FIAN INTERNATIONAL. Written submission by FIAN international. OEIWG, 2015. Available in: <http:// www.ohchr.org/Documents/HRBodies/HRCouncil/ WGTransCorp/Session1/FIAN_International.doc>.

FIAN INTERNATIONAL. Oral statement of FIAN international: panel IV. OEIGWG, 2015. Available in: <http://www.ohchr.org/Documents/HRBodies/HRCouncil/WGTransCorp/Session1/Panel4/Others/ FoodFirst_Information_and_Action_NetworkFIAN. pdf $>$.

FIAN INTERNATIONAL. Oral statement of FIAN international: panel VI. OEIGWG, 2015. Available in: <http://www.ohchr.org/Documents/HRBodies/HRCouncil/WGTransCorp/Session1/Panel6/Others/ FoodFirst_Information_and_Action_Network_FIAN. pdf $>$.

FIDH. Panel IV: Scope/Human rights to be covered under the instrument with respect to activities of TNCs and other business enterprises?. OEIGWG, 2015. Available in: <http://www.ohchr.org/Documents/ HRBodies/HRCouncil/WGTransCorp/Session1/Panel4/Others/International_Federation_for_Human_ Rights_Leagues_FIDH.pdf>.

FIDH. Panel VI: enhancing the responsibility of TNCs and other business enterprises to respect human rights, including prevention, mitigation and remediation. OEIGWG, 2015. Available in: <http://www.ohchr. org/Documents/HRBodies/HRCouncil/WGTransCorp/Session1/Panel6/Others/International_Federation_for_Human_Rights_Leagues_FIDH.pdf $>$.

FITZMAURICE, Malgosia. Contemporary issues in international environmental law. Edward Elgar, 2009.

FRANCIONE, Francesco. Principle 1: human beings and the environment. In: VIÑUALES, Jorge (Ed.). The Rio declaration on environment and development. a commentary. United Kingdom: Oxford University Press, 2015.

FRIENDS OF THE EARTH INTERNATIONAL. Written statement submitted by friends of the earth international. OEIWG, 2015.

FRIENDS OF THE EARTH INTERNATIONAL. Oral statement FoEI at panel VII on legal liability of TNCs and other business enterprises. OEIGWG, 2015. Available in: <http://www.ohchr.org/Documents/HRBodies/ HRCouncil/WGTransCorp/Session1/Panel7/Others/ 
Friends_of_the_Earth_International.pdf $>$.

FOLEY SMITH, Erin. Right to remedies and the inconvenience of forum non conveniens: opening U.S. courts to victims of corporate human rights abuses. Columbia Journal of Law and Social Problems, v. 44, n. 2, p.145-192, 2010.

FORST, Michel. Situation of human rights defenders: report of the special rapporteur on the situation of human rights defenders. A/70/217, 2015.

GANESAN, Arvid. Towards a business and human rights treaty?. In: BAUMANN-PAULY, Dorothée; NOLAN, Justine (Ed.). Business and human rights: from principles to practice. Routledge, 2016.

GELFAND, Jacob. The lack of enforcement in the united nations draft norms: benefit or disadvantage?. In: SCHUTTER, Olivier De (Ed.). Transnational corporations and human rights. Hart Pub, 2006.

GHAFELE BASHI, Roya; MERCER, Angus. "Not starting in sixth gear". UC Davis Journal of International Law and Policy, v. 17, n. 1, p. 41-61, 2011.

GLOBAL CAMPAIGN TO DISMANTLE CORPORATE POWER AND STOP IMPUNITY. Eight proposals for the new legally binding international instrument on transnational corporations and human rghts. OEIWG, 2015. Available in: <http://www.ohchr.org/Documents/ HRBodies/HRCouncil/WGTransCorp/Session1/ Global_Campaign_to_Dismantle_Corporate_Power_ andStop_Impunity_June-2015_en.pdf > .

GRADL, Christina et al. Fast growth and big impacts: how emerging market multinationals are advancing sustainable development. Deutsche Gesellschaft für Internationale Zusammenarbeit (GIZ). 2011.

HANDL, Günter. Human rights and the protection of the environment. In: EIDE, Asbjørn; KRAUSE, Catarina; ROSAS, Allan (Ed.). Economic, social \& cultural rights: a textbook. 2. ed. M Nijhoff Publishers. 2001.

HOBBES, Michael. The untouchables. Foreign Policy, 2016. Available in: <https://foreignpolicy. com/2016/04/11/the-untouchables-zimbabwe-greenfuel-multinational-corporations $/>$.

INDONESIAN DELEGATION. Statement by Indonesian delegation at the 1st session of the open-ended intergovernmental working group on transnational corporations and other business enterprises with respect to buman rights, 2015. Available in: <http://www.ohchr.org/Documents/
HRBodies/HRCouncil/WGTransCorp/Session1/GeneralComments/States/Indonesia1.pdf>.

INTER-AMERICAN COURT OF HUMAN RIGHTS. Claude-Reyes et al v Chile: merits, reparations and costs. IACtHR Series C, n. 15, 2006.

INTER-AMERICAN COURT OF HUMAN RIGHTS. International responsibility for the promulgation of laws in violation of the convention: advisory opinion. IACtHR OC14/94, 1994.

INTER-AMERICAN COURT OF HUMAN RIGHTS. Kaliña and Lokono peoples v Suriname: merits, reparations and costs). IACtHR Series C, n. 309, 2015.

INTER-AMERICAN COURT OF HUMAN RIGHTS. Kawas-Fernández v. Honduras: merits, reparations and costs. IACtHR Series C, n. 196, 2009.

INTER-AMERICAN COURT OF HUMAN RIGHTS. Kichwa indigenous people of Sarayaku v. Ecuador: merits and reparations. IACtHR Series C, n. 245, 2012.

INTER-AMERICAN COURT OF HUMAN RIGHTS. Saramaka people v suriname: preliminary objections, merits, reparations, and costs). IACtHR Series C, n. 172, 2007.

INTER-AMERICAN COURT OF HUMAN RIGHTS. Velásquez-Rodríguezv Honduras: merits. IACtHR Series C, n. 04, 1988.

INTERGOVERNMENTAL PANEL ON CLIMATE CHANGE (Ed.). Climate Change 2014: synthesis report, 2015.

INTERNATIONAL COURT OF JUSTICE. International Court of Justice Reports of Judgments, Advisory Opinions and Orders. Barcelona traction, light and power company, limited, judgment Belgium v Spain, 1970.

INTERNATIONAL LABOUR ORGANIZATION - ILO. Convention concerning indigenous and tribal peoples in independent countries. International Legal Materials, v. 28, n. 6, p. 1382-1392, 1986.

INTERNATIONAL LABOUR ORGANIZATION - ILO. Tripartite declaration of principles concerning multinational enterprises and social policy. International Legal Materials, v. 41, n. 1, p. 184-201, 2002.

INTERNATIONAL MARITIME ORGANIZATION. International convention on civil liability for oil pollution damage. The American Journal of International Law, v. 64, n. 2, 1970. 
INTERNATIONAL MARITIME ORGANIZATION. International convention on the establishment of an international fund for compensation for oil pollution damage: 1971. Environmental Policy and Law, v. 13, n. 2, p. 61-65, 1984.

INTERNATIONAL NETWORK FOR ECONOMIC, SOCIAL AND CULTURAL RIGHTS. Joint oral statement on the scope of the legally binding instrument: TNCs and other business enterprises. OEIGWG, 2015. Available in: <http://www.ohchr.org/Documents/HRBodies/HRCouncil/WGTransCorp/Session1/Panel3/ Others/ESCR-NET_Joint_Statement.pdf $>$.

IROGBE, Kema. Global political economy and the power of multinational corporations. Journal of Third World Studies, v. 30, n. 2, 2013.

JAWOREK, Małgorzata; KUZEL, Marcin. Transnational corporations in the world economy: formation, development and present position. Copernican Journal of Finance \& Accounting, v. 4, n. 1, p. 55-77, 2015.

JONGE, Alice de. Transnational corporations and international law: accountability in the global business environment. Edward Elgar Pub, 2011.

K. ANTON, Donald; SHELTON, Dinah. Environmental protection and human rights. Cambridge University Press, 2011.

KAMMINGA, Menno. Company responses to human rights reports: an empirical analysis. Business and Human Rights Journal, v. 1, n. 1, p. 95-110, 2016.

KATUOKA, Saulius; DAILIDAITE, Monika. Responsibility of transnational corporations for human rights violations: deficiencies of international legal background and solutions offered by national and regional legal tools. Jurisprudencija, v. 19, n. 4, p. 1301- 1316, 2012.

KHAN, Wasima. Corporate power and the protection of human rights in equilibrium. Security and Human Rights, v. 24, n. 1, p. 29-42, 2013.

KHOURY, Stéfanie. Transnational corporations and the european court of human rights: reflexions on the indirect and direct approaches to accountability. Oñati Journal of Emergent Socio-Legal Studies, v. 4, n. 1, p. 68-110, 2010.

KIMERLING, Judith. Remarks by Judith Kimerling. Proceedings of the Annual Meeting: american Society of International Law, v. 106, p. 416-419, 2012.
KNOX, John. Greening human rights. OpenDemocracy, 14 Jul 2015. Available in: <https://www.opendemocracy.net/openglobalrights/john-knox/greening-humanrights $>$.

KNOX, John. Horizontal human rights law. The American Journal of International Law, v. 102, n. 1, p. 1-47, 2008.

KNOX, John. Human rights, environmental protection, and the sustainable development goals. Washington International Law Journal, v. 24, n. 4, p. 517-536, 2015.

KNOX, John. Report of the independent expert on the issue of human rights obligations relating to the enjoyment of a safe, clean, bealthy and sustainable environment, compilation of good practices. UN Doc. A/HRC/28/61, 2015.

KNOX, John. Report of the special rapporteur on the issue of buman rights obligations relating to the enjoyment of a safe, clean, healthy and sustainable environment. A/HRC/31/52, 2016.

KOSKENNIEMI, Martti. Hegemonic regimes. In: YOUNG, Margaret (Ed.). Regime interaction in international law. United Kingdom: Cambridge University Press, 2011.

KRAMER, Xandra. UK court on tort litigation against transnational corporations: conflicts of laws. Available in: $<$ http://conflictoflaws.net/2016/uk-court-on-tort-litigation-against-transnational-corporations $/>$.

KRAVIAS, Markos. Corporate obligations under international law. United Kingdom: Oxford University Press, 2013.

KREMNITZER, Mordechai. A possible case for imposing criminal liability on corporations in international criminal law. Journal of International Criminal Justice, v. 8, n. 3, p. 909-918, 2010.

LAGOUTTE, Stéphanie. New challenges facing states within the field of human rights and business. Nordic Journal of Human Rights, v. 33, n. 2, p. 158-180, 2015.

LAVRYSEN, Luc. The Aarhus Convention: between environmental protection and human rights. In : MARTENS, Paul; MELCHIOR, Michel (Ed.). Liège, Strasbourg. Bruxelles: parcours des droits de l'homme, Anthémis, 2010.

LEAGUE OF ARAB STATES. Arab charter on human rights, 2004.

LÓPEZ, Carlos. The "ruggie process": from legal obligations to corporate social responsibility? In: DEVA, Surya; BILCHITZ, David (Ed.). Human rights obligations of business. Cambridge University Press, 2013. 
LOPEZ, Carlos; SHEA, Ben. Negotiating a treaty on business and human rights: a review of the first intergovernmental session. Business and Human Rights Journal, v. 1, n. 1, p. 111-116, 2016.

LUPPI, Barbara; PARISI, Francesco; RAJAGOPALAN, Shruti. The rise and fall of the polluter-pays principle in developing countries. International Review of Law and Economics, v. 32, n. 1, p. 135-144, 2012.

MACLEAY, Fiona. Corporate codes of conduct and the human rights accountability of transnational corporations: a small piece of a larger puzzle. In: SCHUTTER, Olivier De (Ed.). Transnational corporations and buman rights. Hart Pub, 2006.

MALJEAN-DUBOIS, Sandrine; RICHARD, Vanessa. The applicability of international environmental law to private enterprises. In: DUPUY, Pierre-Marie; VIÑUALES, Jorge (Ed.). Harnessing foreign investment to promote environmental protection. United Kingdom: Cambridge University Press, 2013.

MASSARANI, Tarek; TATGENHORST DRAKOS, Margo; PAJKOWSKA, Joanna. Extracting corporate responsibility: towards a human rights impact assessment. Cornell International Law Journal, v. 40, n. 1, p. 135169, 2007.

MCBETH, Adam. Human rights in economic globalisation. In: JOSEPH, Sarah; MCBETH, Adam (Ed.). Research handbook on international human rights law. Edward Elgar, p. 139-141, 2010.

MCCONNELL, Lee. Establishing liability for multinational oil companies in parent/subsidiary relationships case note. Environmental Law Review, v. 16, n. 1, p. 50-59, 2014.

MCCORQUODALE, Robert. Principles for an internationally legally binding instrument on TNC and other business enterprises with respect to buman rights. Available in: <http:// www.ohchr.org/Documents/HRBodies/HRCouncil/ WGTransCorp/Session1/McCorquodaleIGWGPanel060715.pdf>.

MERINO BLANCO, Elena; PONTIN, Ben. Litigating extraterritorial nuisances under english common law and UK statute. Transnational Environmental Law, v. 6, n. 2, p. 285-308, 2017.

MISTURA, Alessandra. Is there space for environmental crimes under international criminal law?: the impact of the office of the prosecutor policy paper on case selection and prioritization on the current legal framework. Columbia Journal of Environmental Law, v. 43, n. 1, p. 181-226, 2018.

MOHAMADIEH, Kinda; URIBE, Daniel. Business and buman rights: commencing discussions on a legally binding instrument. South Centre Bulletin. Available in: $\quad<$ http://www.southcentre.int/wp-content/uploads/2015/11/SB87-88_EN.pdf>.

MORGERA, Elisa. Benefit-sharing as a bridge between the environmental and human rights accountability of multinational corporations. In: BOER, Ben. (Ed.). Environmental law dimensions of human rights. United Kingdom: Oxford University Press, 2015.

MORGERA, Elisa. Corporate accountability in international environmental law. United Kingdom: Oxford University Press, 2009.

MORGERA, Elisa. From corporate social responsibility to accountability mechanisms. In: DUPUY, Pierre-Marie; VIÑUALES, Jorge (Ed.). Harnessing foreign investment to promote environmental protection. United Kingdom: Cambridge University Press, 2013.

MORGERA, Elisa. Multinational corporations and international environmental law. In: ALAM, Shawkat et al. (Ed.). Routledge handbook of international environmental law. Routledge, 2015.

MORGERA, Elisa. The UN and corporate environmental responsibility: between international regulation and partnerships. Review of European Community and International Environmental Law, v. 15, n. 1, p. 93-109, 2006.

MUCHLINSKI, Peter. Corporations in international law. In: WOLFRUM, Rudiger (Ed.). Max Planck encyclopaedia of public international law. United Kingdom: Oxford University Press, 2014.

MÜLLEROVÁ, Hana. Environment playing shorthanded: margin of appreciation in environmental jurisprudence of the european court of human rights: environment playing short-handed. Review of European, Comparative \& International Environmental Law, v. 24, n. 1, p. 83-92, 2015.

NAMIBIAN DELEGATION. Panel III. OEIGWG, 2015. Available in: <http://www.ohchr.org/Documents/HRBodies/HRCouncil/WGTransCorp/Session1/Panel3/States/Namibia.pdf $>$.

NARINE, Marcia. From Kansas to the Congo: why 
naming and shaming corporations through the DoddFrank act's corporate governance disclosure won't solve a human rights crisis emerging issues in social enterprise. Regent University Law Review, v. 25, p. 351-401, 2012.

NOLAN, Justine. A business and human rights treaty. In: BAUMANN-PAULY, Dorothée; NOLAN, Justine (Ed.). Business and human rights: from principles to practice. Routledge, 2016.

NOLAN, Justine. The corporate responsibility to respect human rights: soft law or not law? In: DEVA, Surya; BILCHITZ, David (Ed.). Human rights obligations of business. United Kingdom: Cambridge University Press, 2013.

NOLLKAEMPER, André. Responsibility of transnational corporations in international environmental law: three perspectives. In: WINTER, Gerd (Ed.). Multilevel governance of global environmental change. United Kingdom: Cambridge University Press, 2006.

NOLLKAEMPER, André. Sovereignty and environmental justice in international law. In: EBBESSON, Jonas; OKOWA, Phoebe (Ed.). Environmental law and justice in context. United Kingdom: Cambridge University Press, 2009.

ORELLANA, Marcos; KOTHARI, Miloon; CHAUDHRY, Shivani. Climate change in the work of the committee on economic, social and cultural rights. Geneva: Friedrich Ebert Stiftung, 2010.

ORGANISATION FOR ECONOMIC CO-OPERATION AND DEVELOPMENT. OECD guidelines for multinational enterprises, 2011.

ORGANIZATION OF AFRICAN UNITY. African charter on human and peoples' rights. OAU Doc. CAB/ LEG/67/3 rev, 1981.

ORGANISATION OF AMERICAN STATES. Additional protocol to the american convention on buman rights in the area of economic, social and cultural rights, 1988.

PAVONI, Riccardo. Environmental jurisprudence of the european and inter-american courts of human rights. In: BOER, Ben (Ed.). Environmental law dimensions of buman rights. United Kingdom: Oxford University Press, 2015.

RAMASASTRY, Anita. Corporate complicity: from Nuremberg to Rangoon: an examination of forced labor cases and their impact on the liability of multinational corporations Stefan A. Riesenfeld symposium 2001.
Berkeley Journal of International Law, v. 20, n. 1, p. 91-159, 2002.

RAMASASTRY, Anita. Corporate social responsibility versus business and human rights: bridging the gap between responsibility and accountability. Journal of $\mathrm{Hu}$ man Rights, v. 14, n. 2, p. 237-259, jun. 2015.

RAMCHARAN, Bertrand. The law, policy and politics of the UN. Brill Nijhoff, 2015.

RUGGIE, John. A UN business and buman rights treaty? Available in: <https://www.hks.harvard.edu/m-rcbg/ CSRI/UNBusinessandHumanRightsTreaty.pdf $>$.

RUGGIE, John. Business and human rights: further steps toward the operationalization of the "protect, respect and remedy" framework: report of the special representative of the secretary general on the issue of human rights and transnational corporations and other business enterprises. UN Doc. A/HRC/14/27, 2010.

RUGGIE, John. Guiding principles on business and buman rights: implementing the United Nations "protect, respect and remedy" Framework. A/HRC/17/31, 2011.

RUGGIE, John. Just business: multinational corporations and human rights. W. W Norton \& Company, 2013.

RUGGIE, John. Protect, respect and remedy: a framework for business and human rights: report of the special representative of the secretary-general on the issue of human rights and transnational corporations and other business enterprises, A/HRC/8/5, 2008.

RUGGIE, John. Report of the special representative of the secretary-general on the issue of buman rights and transnational corporations and other business enterprises. Addendum: corporations and human rights: a survey of the scope and patterns of alleged corporate-related human rights abuse. A/HRC/8/5/Add.2, 2008.

RUGGIE, John. Report of the special representative of the secretary general on the issue of human rights and transnational corporations and other business enterprises. Report submitted before session 17 of the human rights council. A/ HRC/17/31, 2011.

RUGGIE, John. The past as prologue?: a moment of truth for UN business and human rights treaty. Available in: $<$ https://www.hks.harvard.edu/m-rcbg/CSRI/Treaty_Final.pdf $>$.

SADELEER Nicolas de. Environmental justice and international trade law. In: EBBESSON, Jonas; OKOWA, 
Phoebe (Ed.). Environmental law and justice in context. United Kingdom: Cambridge University Press, 2009.

SANDS, Philippe. Principles of international environmental law. 2. ed. Cambridge University Press, 2003.

SAUL, Matthew. The european court of human rights' margin of appreciation and the processes of national parliaments. Human Rights Law Review, v. 15, n. 4, p. 745$774,2015$.

SAUVANT, Karl. The negotiations of the United Nations code of conduct on transnational corporations: experience and lessons learned. The Journal of World Investment \& Trade, v. 16, p. 11-87, 2015.

SCHRÖDER, Meinhard. Precautionary approach/ principle. In: WOLFRUM, Rudiger (Ed.). Max Planck encyclopaedia of public international law. United Kingdom: Oxford University Press, 2014.

SCHUTTER, Olivier De; SKINNER, Gwynne; MCCORQUODALE, Robert. The third pillar: access to judicial remedies for human rights violations by transnational business. International Corporate Accountability Roundtable, 2013.

SCHWARTZ, Priscilla. Corporate activities and environmental justice: perspectives on Sierra Leone's mining. In: EBBESSON, Jonas; OKOWA, Phoebe (Ed.). Environmental law and justice in context. Cambridge University Press, 2009.

SECK, Sara. Canadian mining internationally and the UN guiding principles for business and human rights. Canadian Yearbook of International Law, v. 49, p. 51-116, 2011.

SECRETARIAT OF THE CONVENTION ON BIOLOGICAL DIVERSITY. Akwé Kon: voluntary guidelines for the conduct of cultural, environmental, and social impact assessments regarding developments proposed to take place on, or which are likely to impact on, sacred sites and on lands and waters traditionally occupied or used by indigenous and local communities, 2004.

SECRETARIAT OF THE CONVENTION ON BIOLOGICAL DIVERSITY (Ed.). Cartagena protocol on biosafety to the convention on biological diversity: text and annexes, 2000.

SETHI, S. Prakash; SCHEPERS, Donald H. United Nations global compact: the promise-performance gap. Journal of Business Ethics, v. 122, n. 2, p. 193-208, 2013.
SHANY, Yuval. Toward a general margin of appreciation doctrine in international law? European Journal of International Law, v. 16, n. 5, p. 907-940, 2005.

SHAW, Malcolm. International law. 6. ed. United Kingdom: Cambridge University Press, 2008.

SHELTON, Dinah. Legitimate and necessary: adjudicating human rights violations related to activities causing environmental harm or risk. Journal of Human Rights and the Environment, v. 6, n. 2, p. 139-155, 2015.

SHELTON, Dinah. Normative hierarchy in international law. The American Journal of International Law, v. 100, n. 2, p. 291-323, 2006.

SHELTON, Dinah; BEDERMAN, David. Tătar C. Roumanie. The American Journal of International Law, v. 104, n. 3, p. 247-252, 2010.

SIMONS, Penelope. International law's invisible hand and the future of corporate accountability for violations of human rights. Journal of Human Rights and the Environment, v. 3, n. 1, p. 5-43, 2012.

STEFFEN, Will; CRUTZEN, Paul; MCNEILL, John. The anthropocene: are humans now overwhelming the great forces of nature? Ambio, v. 36, n. 8, p. 614-621, 2007.

STEPHENS, Beth. Are corporations people?: corporate personhood under the constitution and international law: an Essay in honor of professor Roger S. Clark. Rutgers Law Journal, v. 44, n. 1, p. 1-31, 2013.

SOUTH AFRICAN DELEGATION. Opening statement delivered by South Africa. Available in: <http:// www.ohchr.org/Documents/HRBodies/HRCouncil/ WGTransCorp/Session1/SOUTHAFRICAS_Opening_StatementbyAmbMinty_Panel1.pdf $>$.

SOUTH AFRICAN DELEGATION. Panel IV : human rights to be covered under the instrument with respect to activities of TNCs and other business enterprises? OEIGWG, 2015. Available in: <http://www.ohchr. org/Documents/HRBodies/HRCouncil/WGTransCorp/Session1/Panel4/States/SouthAfrica.doc>.

SOUTH AFRICAN DELEGATION. Panel VI: enhancing the responsibility of transnational corporations and other business enterprises to respect human rights, including prevention, mitigation and remediation. OEIGWG, 2015. Available in: <http://www.ohchr. org/Documents/HRBodies / HRCouncil/WGTransCorp/Session1/Panel6/States/South_Africa.pdf $>$. 
SUAREZ, Roberto. Legal liability of transnational corporation. OEIGWG, 2015. Available in: < http://www.ohchr. org/Documents/HRBodies/HRCouncil/WGTransCorp/Session1/Panel7/Roberto_Suarez.pdf>.

TOXIC WATCH ALLIANCE. Proposals for legally enforceable mandatory treaty on transnational corporations, banks, other business enterprises, human rights and its historical context. OEIWG, 2015. Available in: <http://www.ohchr.org/ Documents/HRBodies/HRCouncil/WGTransCorp/ Session1/TWAProposals_for_Legally_Enforceable_ Mandatory_Treaty_on_TNCs_Banks_other_BusinessEnterprisesHumanRights.pdf $>$.

TREATY ALLIANCE. Panel II: scope. OEIGWG, 2015. Available in: <http://www.ohchr.org/Documents/HRBodies/HRCouncil/WGTransCorp/Session1/Panel2/Others/SOMOJointStatement.pdf>.

TRIVET'T, Vincent et al. 25 US mega corporations: where they rank if they were countries. Available in Business Insider at: <http://www.businessinsider.com/25-corporations-bigger-tan-countries-2011-6>.

UN COMMITTEE ON ECONOMIC, SOCIAL AND CULTURAL RIGHTS. General comment no. 24 on State obligations under the international covenant on economic, social and cultural rights in the context of business activities. Treaty Body General Comment E/C.12/GC/24, 2017.

UN OFFICE OF THE HIGH COMMISSIONER FOR HUMAN RIGHTS. Human rights and transnational corporations and other business enterprises. E/CN.4/ RES/2005/69, para. 1, 2005.

UN OFFICE OF THE HIGH COMMISSIONER FOR HUMAN RIGHTS. Report of the office of the United Nations high commissioner for human rights on the relationship between climate change and human rights. Annual Report A/ HRC/10/61, 2009.

UNITED KINGDOM. England and Wales High Court. Pedro Emiro Florez. Arroyo \& others v Equion Energia Limited [formerly BP exploration company (Colombia) limited]. EWHC 1699 (TCC), 2016.

UNITED KINGDOM. England and Wales High Court. The bodo community and others $v$ shell petroleum development company of Nigeria Ltd. EWHC 1973, 2014.

UNITED KINGDOM. House of Lords. Lubbe v Cape PLC. UKHL 41, 2000.

UNITED KINGDOM. United Kingdom House of Lords. Connelly v. RTZ Plc. AC 854, 1998.
UNITED KINGDOM. United Kingdom House of Lords. Lubbe and Ors v. Cape Plc. WLR 1545, 2000.

UNITED NATIONS. Commentary on the norms on the responsibilities of transnational corporations and other business enterprises with regard to human rights. UN Doc E/CN4/ Sub2/2003/38/Rev2, 2003.

UNITED NATIONS. Conventions and agreements international developments. Commonwealth Law Bulletin, v. 19, n. 1, p. 247-316, 1993.

UNITED NATIONS. Norms on the responsibilities of transnational corporations and other business enterprises with regard to buman rights. E/CN4/Sub2/2003/12/Rev2, 2003.

UNITED NATIONS. Official documents United Nations human rights covenants: international covenant on economic, social and cultural rights, international covenant on civil and political rights, optional protocol to the international covenant on civil and political Rrights. American Journal of International Law, v. 61, n. 3, p. 861-890, 1967.

UNITED NATIONS. Review of the composition, organization and administrative arrangements of the sessional working group on the implementation of the international covenant on economic, social and cultural rights. E/1982/L.35/Rev.1, 1985.

UNITED NATIONS. United Nations framework convention on climate change. FCC/INFORMAL/84/Rev1, 1992.

UNITED NATIONS. United Nations conference on environment and development: convention on biological diversity. International Legal Materials, v. 31, n. 4, p. 818-841, 1992.

UNITED NATIONS. United Nations world conference on human rights: Vienna declaration and programme of action. International Legal Materials, v. 32, n. 6, p. 1661 1687, 1993.

UNITED NATIONS. Vienna convention on the law of treaties (1969). New York: Treaty Series, v. 1155, n. 18232, 1987.

UNITED NATIONS. World charter for nature. Environmental Policy and Law, v. 10, n. 2, p. 34-41, 1983.

UNITED NATIONS CONFERENCE ON TRADE AND DEVELOPMENT. Global value chains: investment and trade for development. 2013.

UNITED NATIONS ECONOMIC COMMISSION FOR EUROPE. Convention on access to information, public participation in decision-making and access to 
justice in environmental matters. International Legal Materials, v. 38, n. 3, p. 517-533, 1999.

UNITED NATIONS ECONOMIC COMMISSION FOR LATIN AMERICA AND THE CARIBBEAN. Regional agreement on access to information, participation and justice in environmental matters in Latin America and the Caribbean. 2018.

UNITED NATIONS HUMAN RIGHTS COUNCIL. Human rights and climate change. Resolution A/ HRC/26/L.33, 2014.

UNITED NATIONS HUMAN RIGHTS COUNCIL. Human rights and the environment. UN. Doc. A/HRC/ RES/19/10, 2012.

UNITED NATIONS HUMAN RIGHTS COUNCIL. Human rights and the environment. UN Doc. A/HRC/ RES/25/21, 2014.

UNITED NATIONS HUMAN RIGHTS COUNCIL. Human rights and transnational corporations and other business enterprises. A/HRC/RES/17/4, 2011.

UNITED NATIONS HUMAN RIGHTS COUNCIL. Elaboration of an international legally binding instrument on transnational corporations and other business enterprises with respect to human rights. UN. Doc. A/HRC/RES/26/9, 2014.

UNITED NATIONS HUMAN RIGHTS COUNCIL. Report on the first session of the open-ended intergovernmental working group on transnational corporations and other business enterprises with respect to human rights, with the mandate of elaborating an international legally binding instrument. A/ $\mathrm{HRC} / 31 / 50,2016$.

UNITED NATIONS HUMAN RIGHTS COUNCIL. Report on the second session of the open-ended intergovernmental working group on transnational corporations and other business enterprises with respect to buman rights. A/HRC/34/47, 2017.

UNITED NATIONS HUMAN RIGHTS COUNCIL. Report on the third session of the open-ended intergovernmental working group on transnational corporations and other business enterprises with respect to human rights. A/HRC/37/67, 2018.

UNITED NATIONS INTERNATIONAL LAW COMMISSION. Fragmentation of international law: difficulties arising from the diversification and expansion of international law. Erik Castrén Institute of International Law and Human Rights, 2007.
UNITED NATIONS INTERNATIONAL LAW COMMISSION. Yearbook of the international law commission 2000. Geneva: United Nations, v. 2, part. 2, para. 716, 2005.

UNITED NATIONS INTERNATIONAL LAW COMMISSION. Yearbook of the international law commission 2001. New York: United Nations, v. 2, 2007.

UNITED STATES OF AMERICA. United States District Court for the Central district of California. Doev Unocal Corp. CD California 963 f., supp. 880, 1997.

UNITED STATES OF AMERICA. United States District Court for the Northern District of California. Bowoto v Chevron Corp. ND Cal 481 f., supp. 2d, 1010, 2007.

UNITED STATES OF AMERICA. United States District Court for the Southern District of New York. Agninda v Texaco, Inc. 142 f., supp. 2d, 534, 2001.

UNITED STATES OF AMERICA. United States District Court for the Southern District of New York. Flores v Southern Peru Copper. 253 f., supp. 2d, 510, 2002.

UNITED STATES OF AMERICA. United States District Court for the Southern District of New York. In: Re union carbide corp gas plant disaster at bhopal. 634 f., supp. 842, 2, 1986.

UNITED STATES OF AMERICA. United States Supreme Court. Kiobel et al v Royal Dutch Petroleum Co et al. n. 10-1491, 2013.

VAN DER WILT, Harmen. Corporate criminal responsibility for international crimes: exploring the possibilities. Chinese Journal of International Law, v. 12, n. 1, p. 43-77, 2013.

WEISSBRODT, David. Human rights standards concerning transnational corporations and other business entities. Minnesota Journal of International Law, v. 23, n. 2, p. 135-171, 2014.

WEISSBRODT, David; KRUGER, Muria. Norms on the responsibilities of transnational corporations and other business enterprises with regard to human rights current developments. American Journal of International Law, v. 97, n. 4, p. 901-922, 2003.

WETTSTEIN, Florian. Multinational corporations and global justice: human rights obligations of a quasi-governmental institution. Stanford Business Books, 2009.

WETTSTEIN, Florian. Normativity, ethics, and the 
UN gGuiding principles on business and human rights: a critical assessment. Journal of Human Rights, v. 14, n. 2, p. 162-182, 2015.

WOLFRUM, Rüdiger. Obligation of result versus obligation of conduct: some thoughts about the implementation of international obligations. In: ARSANJANI, Mahnoush and others (Ed.). Looking to the Future. Brill, 2010.
WORKING GROUP ON THE ISSUE OF HUMAN RIGHTS AND TRANSNATIONAL CORPORATIONS AND OTHER BUSINESS ENTERPRISES. Report of the working group on the issue of human rights and transnational corporations and other business enterprises. UN Doc. A/70/216, 2015.

ZAHARAI, Constantin et al. Transnational corporations, international law and human rights. Economics, $\mathrm{Ma}$ nagement \& Financial Markets, v. 6, n. 4, p. 138-143, 2011. 
Para publicar na Revista de Direito Internacional, acesse o endereço eletrônico www.rdi.uniceub.br ou www.brazilianjournal.org.

Observe as normas de publicação, para facilitar e agilizar o trabalho de edição. 